\title{
Blue-Collar Workers Entrepreneurial Intentions and The Extended Theory of Reasoned Action: Incorporating SEM and Person-Item Map Analysis
}

\author{
Hermansyah Andi Wibowo ${ }^{1 *}$, Nurul Indarti ${ }^{2}$ \\ ${ }^{1}$ Department of Management, Faculty of Economics and Business, Universitas Serang Raya, Kota \\ Serang, 42162, Indonesia \\ ${ }^{2}$ Department of Management, Faculty of Economics and Business, Universitas Gadjah Mada, \\ Yogyakarta, 55281, Indonesia
}

\begin{abstract}
Introduction/Main Objectives: Blue-collar workers face major threats related to the development and application of Industry 4.0. Unfortunately, research on how they deal with this situation is scarce in the behavioral science literature. In this study, we attempt to fill this gap by emphasizing a methodological aspect of combining structural equation modeling (SEM) and person-item map analysis to the extended model of the theory of reasoned action. Novelty and Methods: We offer the notion of combining SEM and Rasch model analysis to explain the extended of theory of reasoned action. The respondents were blue-collar workers from Indonesia who have not yet started a business. Finding/Results: In line with our goal of applying intersubjective certification to the extended theory of reasoned action (TRA) model in the context of blue-collar workers, our results suggest that religiosity affects entrepreneurial intentions, both directly and indirectly, through attitude. The subjective norms have also been shown to influence the intention of blue-collar workers to become entrepreneurs. The extended TRA model has been proven empirically to have good predictive power, with a total effect of $83 \%$. Conclusion: Regarding the sample issue, the person-item map is excellent for explaining our SEM-based findings. The idea of combining the Rasch model property, which is a persons-items map, requires more empirical support to promote its ability to illuminate SEM-based research explanations.
\end{abstract}

ARTICLE INFO

JEL Code:

D13, I31, J22, K31
Article information:

Received in 30 November 2019.

Received in revised form 13 May 2020.

Received in revised form 24 June 2020.

Accepted 30 June 2020.

Keywords:

blue-collar workers, nascent entrepreneurs, the theory of reasoned action, religiosity, person-item maps.

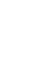

(1)




\section{INTRODUCTION}

In the community, blue-collar workers face enormous impacts from the developments caused by the Industrial Revolution 4.0 (IR 4.0) in their careers. Why? Because labor activities are mechanical in the production/process chain and will be replaced by intellectual activities, viz. the routine automation by smart machine (Bogoviz, Osipov, Chistyakova, \& Borisov, 2019). This replacement is an IR 4.0 practice based on a behavioral conceptual approach where the interaction of the subjects (humans) with the objects (machines) is transformed into the interaction between machines (Sukhodolov, 2019). The "cyber-physical systems" or automatized machines and processing centers, when connected to the internet (Pozdnyakova, Golikov, Peters, \& Morozova, 2019)are capable of working massively, precisely, dynamically, and responsively by being connected through the Internet of Things (IoT). Indeed, new professions may arise from the development of IR 4.0. However, the skills and knowledge needed and the boundaries attached to them (viz. time), make it difficult for blue-collar workers to master them immediately. Wisely, blue-collar workers must prepare for a new profession, namely nascent entrepreneurs, while they have not yet left their present jobs. Therefore, it is vital to know how the entrepreneurial intentions of blue-collar workers formed, and what factors might prove to have had a significant influence of this formation.

In thescientific literature, the theory of reasoned action (TRA) has been widely used by researchers to predict human behavior. Pure components of TRA predict one's intention to buy halal food (Lada, Harvey Tanakinjal, \& Amin, 2009);TRA with the moderating role of ethical ideology on the influence of attitude, as well as the moderating role of low self-control and public self-awareness on the influence of subjective norms, predicts one's intention to commit software piracy (Aleassa, Pearson, \& McClurg, 2011); TRA with a spirituality/ religiosity consideration influences the intention to delay breast cancer screening (Gullatte, 2006). This theory is based on the assumption that humans behave using rational considerations based on their attitudes and the social pressures they perceive. If it is associated with religiosity only, this theory has succeeded in gaining empirical support from the context of hijabwearing behavior (Wibowo, 2017), although it was mediated by attitude. If religiosity, alone, was tested with attitudes and behavior, Wibowo and Masitoh (2018) found that, in addition to the attitudes and behavior influenced by religiosity, religiosity had also eliminated the relationship between attitudes and behavior.

Regarding the topic of nascent entrepreneurs, we argue that starting a business when still in a job is different from starting a business when one is unemployed. Blue-collar workers have a time lag that minimizes their bounded rationality. Their response to the macro-environment becomes increasingly more rational. They can gather valuable information through their cognitive capacity. Furthermore, we were also motivated to continue and deepen our previous structural equation modeling (SEM)-based work (Wibowo, 2017) by re-examining the model in different settings and giving an additional analysis of the persons-items map. With this context and motivation, we chose the extended TRA model to explain the phenomenon. We also focused on the technical discussion about the application and the incorporation of two quantitative models, viz. SEM and the Rasch model.

Next, we formulated the research questions as follows, one, whether the extended TRA model can better predict variations in the intention to start a business? Two, does 
incorporating SEM and the Rasch model provide a better explanation of the model's prescriptive ability? Therefore, the purpose of this research is to re-examine the extended TRA model in the blue-collar workers' setting and to generate prescriptive insights of the verified SEM model by explicating the chosen independent variable with the Rasch model. We expect our work will contribute to the development of TRA with a faith-based orientation. We try to model the psychological decision process that includes one's faith consideration, which has robustness (due to TRA) and parsimony (against the novel TRA, viz. the reasoned action approach (Fishbein \& Ajzen, 2010).

\section{LITERATURE REVIEW}

\section{a. Entrepreneurial intention and the theory of reasoned action (TRA)}

Behavioral intentions, an element of TRA, are closely related to one's actual behavior. Many researchers apply TRA with adequate discussion studies that involve measuring people's attitudes, perceptions, and opinions, but they can only measure intentions. The separation of intention and behavior is plausible because implementing TRA as a complete model requires gathering data from the same person twice. The aim is to confirm the intention to behave with the actual behavior. Even so, pragmatism in applying this theory has dominated and contributed mainly to the development of behavioral science.

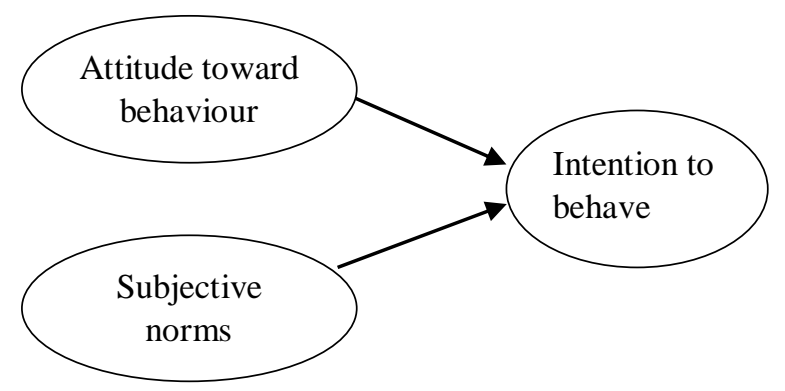

Figure 1. Theory of reasoned action (TRA) Source: Adapted from Fishbein \& Ajzen (1975a)
The intention refers to one's location within the dimension of subjective probability involving the relationship between him/herself and an action. Therefore, the intention to behave is a person's subjective probability that he/she will do something (Fishbein \& Ajzen, 1975b). Meanwhile, attitude is the evaluation of positive or negative beliefs or feelings about something (Fishbein \& Ajzen, 1975a). We define the attitude toward entrepreneurship as an evaluative tendency toward entrepreneurship, based on the belief in the results obtained. Meanwhile, subjective norms are the respondent's perception of other people's opinions about particular objects. Ajzen (2012) stated that subjective norms are a person's perception of the social stresses he/she faces related to behavior. In this study, the object in question was entrepreneurial behavior that is influenced by social pressure or someone's perception of the expectations of others to behave in certain ways.

\section{b. Religiosity Influence on the Entrepre- neurial Intention}

Johnson, Jang, Larson, and Li (2001)argued that religiosity is the level at which a person is committed to his/her religion and its teachings, because one's attitude and behavior reflect this commitment. Religiosity has a personal dimension (Slater, Hall, \& Edwards, 2001) and represents a person's real relationship with holiness. However, Souiden and Rani (2015), stated that the term religiosity shows someone's respect for their religion. According to ElMenouars' (2014) work, religiosity refers to a person's conformance with religious teachings, which are a reflection of basic beliefs, understanding the main tasks, spiritual experience, knowledge, and orthopraxis.

Many researchers have obtained empirical support for the influence of religiosity on attitudes and intentions. Religiosity influences 
the intention to take Islamic loans (Syed Shah Alam, Janor, Aniza, \& Wel, 2012); to act out asexual fantasy (Ahrold, Farmer, Trapnell, \& Meston, 2011); to support legal abortion (Barkan, 2014); to go to the gaming destination, e.g. Las Vegas. However, religiosity is not related to the intention to become a gang member (McKenzie, 2012). Meanwhile, Shakona (2013) and Wibowo (2017)found that attitude purely mediates the effect of religiosity on intention. However, this mediating role is not always supported even though religiosity influences attitudes and intentions (Wibowo \& Masitoh, 2018).

We argue that the values taught in Islam such as one's offspring inheriting one's properties and wealth, giving help to the poor (Al-Bukhari No. 590, n.d.); the belief that Allah is watching and nearby when we serve Him, paying the zakat and perform the Hajj (Nawawi No. 2, n.d.); etc., when socialized adequately to someone, in turn, will provide a basis for others to behave in a certain way. In this case, the behavior in question is entrepreneurial behavior when someone still has a job. Therefore, the level of conformance of a person with Islamic teachings will be both directly or indirectly correlated to his/her intention to decide entrepreneurial behavior. Empirically, in the consistent hijab-wearing behavior's setting, one's religious conformance can lead to the intention to match one's behavior with religious hijab-wearing values (Wibowo \& Masitoh, 2018).

Attitude is an evaluative tendency of hijabwearing behavior, based on one's belief in the results obtained, and it leads to a person favoring a certain direction in the form of judgment, agreeing-disagreeing, or positives-negatives. It is a person's evaluation, whether positive or negative and their beliefs or feelings (Fishbein \& Ajzen, 1975). This study argues that one's religiosity provides input to one's belief in an object, for example, hijab-wearing behavior and/or its effects, and in which it becomes the basis of one's attitude. Empirical evidence that supports this argument can be found in AbouYoussef et al., (2015);); Al Jahwari (2015); Graafland (2015); Schouten and Graafland (2014); Souiden and Rani (2015); Shakona 2013; (Wibowo, 2017).

All the empirical research, reinforces the argument of the positive influence of religiosity on attitudes and on the intention to behave a certain way. Therefore, we proposed the following hypotheses:

H1. Religiosity has positive influences on the entrepreneurial intentions of blue-collar workers

H2. Religiosity has positive influences on the blue-collar workers' attitude toward entrepreneurial behavior

\section{c. Attitude's Influence on Entrepreneurial Intention}

Attitude is divided into two categories (Fishbein \& Ajzen, 1975a): attitude toward objects and attitude toward behavior. Meanwhile, Azwar (2013) stated that attitude is an evaluative response, it means that attitude arises based on the evaluation process of the individual who assigns conclusions (Lada et al., 2009) to the stimulus in the form of good or bad, positive or negative, and pleasant or unpleasant. This then creates a potential reaction toward the object. The attitude toward the act of entrepreneurship is the focus of this research, which is defined as an evaluative tendency toward entrepreneurship based on the belief in the results obtained.

Generation Y's attitudes have proven to influence the intention to buy halal products (Khalek \& Ismail, 2015), to take sharia mortgages (Alam, Janor, Zanariah, \& Ahsan, 2012), and to stay at sharia hotels (Shakona, 
2013). Attitudes also affect the intention to become a customer of Islamic banks (Souiden \& Rani, 2015). Furthermore, in the context of the intention to hijack digital material, attitudes towards piracy also have a positive effect (Yoon, 2011). More specifically, Schouten and Graafland (2014) revealed that some dimensions of the attitude towards corporate social responsibility (CSR) have a positive impact on some of the behavior in executing CSR.

All the empirical research provides support for the positive influence of attitude on the intention to behave in a certain way. Therefore, we proposed the following hypothesis:

H3. Attitudehas positive influences on bluecollar workers' entrepreneurial intentions

\section{d. Subjective Norm's Influence on Entrepre- neurial Intention}

Subjective norms are the respondents' perceptions of other people's opinions about certain objects. Ajzen (2012) stated that subjective norms are a person's perception of the social stresses he or she faces related to his/her behavior. In this study, the object in question was entrepreneurial behavior, which is influenced by social pressure or someone's perception of the expectations of others to behave in certain ways. A number of studies have been conducted to test the significance of this influence. For example, Lada et al. (2009) found that subjective norms influenced the intention to buy halal products, and Khalek and Ismail (2015) found that subjective norms influenced Generation Y to buy halal food. The influence of subjective norms on the intention to hijack digital material is also significant (Yoon, 2011). However, subjective norms are not proven to have any effect on the intention to use Islamic financial systems (Syed Shah Alam et al., 2012).
The information about important social actors for the respondents was, obtained from interviews with 20 of the respondents. Statements from the respondents revealed that the important social actors for blue-collar workers were their parents, lecturers, spouses, and workmates and that these people influenced the respondents' decisions to become entrepreneurs. This condition is consistent with some of the research described and is therefore worthy of testing.

H4. Subjective norms influence the entrepreneurial intentions of blue-collar workers

Some researchers argue that religiosity is a mono dimensional construct, but many of them agree that it is multidimensional (Souiden \& Rani, 2015). However, it seems that some researchers preferred to apply religiosity as a single construct (see JOHNSON et al. (2001), Shakona (2013), Barkan (2014), Al Jahwari (2015), etc.) particularly when the research model has a great deal of complexity. Moreover, religiosity also does not, as yet have a general definition which is accepted by the scientific community. Religiosity is considered to consist of many concepts that may be related to each other in different ways (Mahudin, Noor, Dzulkifli, \& Janon, 2016). A theologist would say that religiosity is faith; psychologists would consider it to be piety; and, for sociologists, it is considered membership (Holdcroft, 2006). Furthermore, scientific perspectives from various established disciplines contribute to this complexity.

Religiosity is the basis for one's beliefs about an object (Wibowo \& Masitoh, 2018), which can also be interpreted as being very likely to influence the way people judge an object, i.e. the attitude toward entrepreneurship. Religiosity is not related to the perspective of others, including how one perceives this perspective to be, i.e. 
subjective norms. We argue the values taught in Islam, such as independency, helping the poor, and perfecting work, when socialized adequately to someone, will in turn, provide a basis for one to have an attitude to them, and behave in a certain way.

Our argument can be seen in the research framework depicted in Figure 2.

\section{e. Why the Rasch Model?}

Rasch's model is the implementation of a new paradigm of measurement in marketing (Salzberger \& Koller, 2013). This statement is correct, in the broader context of measurements related to the latent variables in many disciplines. For nearly half a century, latent variables such as attitudes, opinions, and perceptions were measured with the assumption that the results can be calculated as interval data types, and are on a continuum. Even measurements using a Likert scale produce ordinal-type data, but we take it for granted and consider it to be an interval data type. Therefore, the distance between strongly agree and agree (5 minus 4 ) is the same as the distance between disagree and strongly disagree (2 minus 1 ), which is one interval. The Rasch model can restore data according to its natural conditions (Sumintono \& Widhiarso, 2016). For example, human attitudes that are naturally continuous and become discrete when measured on a Likert scale are then transformed using continuous probabilities. Interestingly, the Rasch model can also distinguish the differing abilities of respondents who have the same total score (Sumintono \& Widhiarso, 2016).

We offer the notion of combining SEM with the Rasch model. In SEM, the researcher must determine what variables scientifically represent the phenomenon of the problem. Then, theoretical and empirical support is sought for the preceding variables up to the earliest variable (independent variable). The explanation chain can be stated even more simply by starting at the end (HUNT, 1991). Once the pattern of relationships between variables is verified, the model must be confidently applied by conducting additional research that cannot be generalized, i.e. qualitative research. The Rasch model provides generalizability and can perform as an alternative to qualitative research.

The Rasch model can provide a thorough overview of the ability of the respondents and the level of difficulty of items to agree on. We can visually calibrate the position of each measure side by side using a persons-items map. The calibration between responses and items offers great potential sources to provide an adequate explanation of SEM-based research. We analyzed all the indicators, even if those indicators were omitted for the goodness of fit in SEM-based research. As the Rasch model

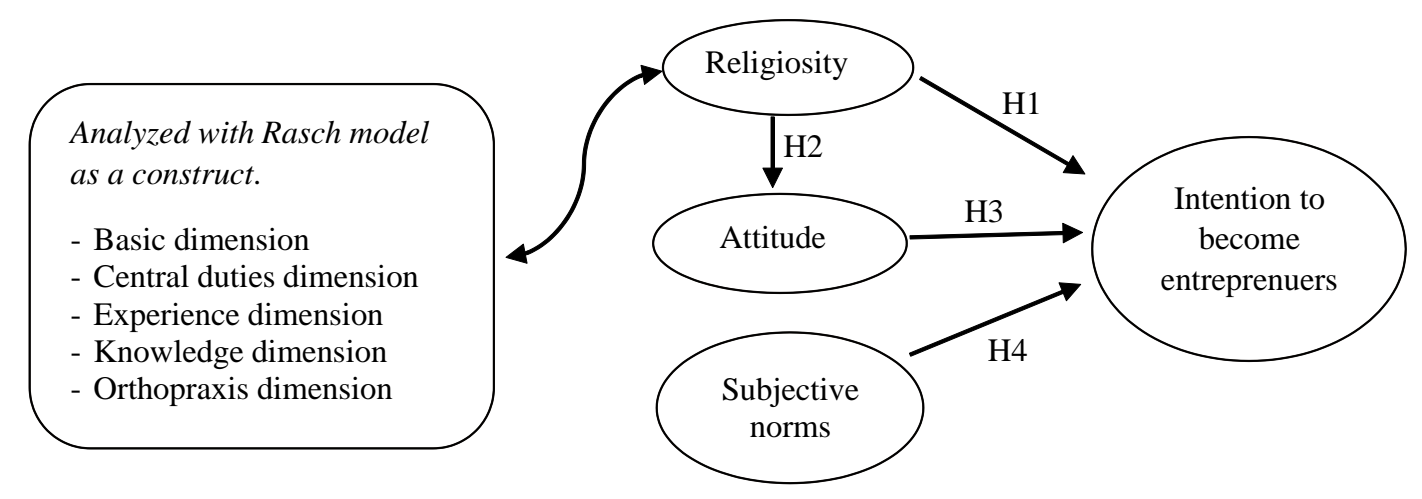

Figure 2. Research Framework 
assumes the measured construct is mono dimensional and was adapted to the context of this study, we chose religiosity as an important variable to obtain valuable information regarding the extended TRA model).

\section{METHOD, DATA, AND ANALYSIS}

\section{a. Data and measurement}

This study took place in the following four cities and four districts of Indonesia: Serang City, Serang Regency, Cilegon City, Pandeglang Regency, Lebak Regency, Tangerang City, Tangerang Regency, and South Tangerang City. We collected data by purposive sampling based on the following criteria: blue-collar workers who have not yet started a business, Muslim males and females whose religion was proven by their ID cards or personal recognition. A total of 474 respondents completed the questionnaire but only 459 were accepted, the rest were rejected for incomplete biodata (i.e., sex and age). The Mahalanobis distance (MD) for multivariate outlier detection (probabilities of MD is smaller than 0.001, Grande, 2015) resulted in the elimination of a further 23 respondents; therefore, the final total number of respondents was 436 .

Observations on several respondents were carried out physically. Unstructured interviews with 20 respondents were carried out in a classroom, and the process was kept confidential from the other respondents. Questionnaires were distributed and filled out by the respondents. Religiosity variables were measured using a scale from El-Menouar (2014).The attitude toward entrepreneurship, subjective norms and entrepreneurial intention was measured by adapting the scale of Ajzen (2010). Particularly, for thesubjective norms, the interview revealed parents, spouses, boyfriends/girlfriends, lecturers, and co-workers as the important social actors of the 20 respondents. The indicators are quantified using a commensurate Likert score with a score of 1 to 5 , where 1 = strongly disagree, $2=$ disagree, $3=$ doubt, $4=$ agree, $5=$ strongly agree.

\section{b. Structural equation modeling}

LISREL 8.54 was utilized to apply the convergent validity testing with confirmatory factor analysis(CFA), in which the latent variables had sufficient convergence if the minimum factor loading value of each item or indicator was 0.5 : ideally 0.7 or higher(Hair Jr., Black, Babin, \& Anderson, 2014).Because there was an exploratory element by including indicators of the sample's religiosity, we do a factor analysis before the SEM (see appendix). Moreover, the scale of religiosity that was used(El-Menouar, 2014) still left room for modification. The discriminant validity was obtained when the inter-constructs squaredcorrelations were less than the average variance extracted (AVE) of the construct. Reliability was tested by the composite reliability (CR) value, with a cut off greater than 0.70 , and AVE, with a cut-off value of 0.5 (Hair Jr. et al., 2014). The results of the goodness of fit (GoF) test of the structural model using the root mean square error of approximation (RMSEA) value criteria of $<0.08$, and normed fit index (NFI), nonnormed fit index NNFI, comparative fit index (CFI), incremental fit index (IFI), relative fit index (RFI), and goodness of fit index (GFI) each should be above 0.9. The absence of agreement on the absolute GoF criteria of SEM (Wijanto, 2008) underlies the selection of seven GoF criteria in this study. Acceptance or rejection of the research's hypothesizes were determined by the significance of the path coefficients in the structural model. A significant path existed when the value of the t-statistics > 1.96 at significance level $\alpha=5 \%$. The latent variable score (LVS) was used to both simplify the religiosity construct and maintain the representation of each dimension. 


\section{c. Rasch model}

To calibrate between response and item, we used one of the Rasch model's properties, namely person-item/Wright's map. In the Rasch model, validity is evidence gathered to support the inferences made from responses to explicate the meaningfulness of a measured construct through examining the person fit, item fit, and item and person ordering and the like (Bond \& Fox, 2015). Further, validity is determined by looking at INFIT and OUTFIT mean square (MNSQ) scores, dus INFIT and OUTFIT $\mathrm{z}$ standardized (ZSTD). The scores to be declared valid for these four (two each, for person and item) criteria are as follows: $0.5<\mathrm{MNSQ}<1.5$, conformity of accepted $\mathrm{z}$ test values $-2.0<$ ZSTD $<2.0$ (Sumintono \& Widhiarso, 2016). Reliability in the Rasch model comprised of three elements: the reliability of the person, the items, and the results of the interaction between the response and the item, i.e. Cronbach's alpha. The cut off for the three types of reliability should be greater than 0.6 (Sumintono \& Widhiarso, 2014).

We analyzed religiosity as the chosen variable, which consisted of five dimensions. In the SEM model, religiosity's dimensions were transformed into indicators for religiosity's constructs by the LVS technique. This was because we examined the effect of religiosity rather than the influence of its constituent dimensions. However, the Rasch model requires that the analyzed variables be mono dimensional. Based on this assumption, we re-analyzed all the indicators of religiosity, including both the existing indicators and those that were eliminated to achieve a SEM model fit. On the person-item map, we still showed the remaining indicators of religiosity in the structural model with red colors.

\section{RESULT AND DISCUSSION}

\section{a. SEM results}

We obtained satisfactory results for the convergent validity test with only the valid manifest variables which are shown in Table 1 (see appendix), and we also had excellent construct reliability which was higher than 0.7 (Hair Jr. et al., 2014). The latent variable technique (LVS) (Wijanto, 2008) transformed five dimensions into five indicators, namely basic, central duties (Cendut), experience (Exprn) knowledge, and orthopraxis. The last two were not valid and thus eliminated from the measurement model. Table 2 (see appendix) shows that the discriminant validity test results were satisfactory because all the average variance extracted (AVE) values of every variable exceeded the squared correlation

Table 4. Hypotheses test results

\begin{tabular}{|c|c|c|c|c|c|}
\hline Hypothesis & Path & Estimate & $\begin{array}{c}\text { Std. } \\
\text { Solution }\end{array}$ & t stats. & Decision \\
\hline H1 & $\begin{array}{l}\text { Religiosity } \rightarrow \text { Entrepreneural } \\
\text { intention }\end{array}$ & 0.3 & 0.25 & 4.16 & Accepted \\
\hline $\mathrm{H} 2$ & Religiosity $\rightarrow$ Attitude & 0.46 & 0.42 & 6.66 & Accepted \\
\hline H3 & $\begin{array}{c}\text { Attitude } \rightarrow \text { Entrepreneurial } \\
\text { intention }\end{array}$ & 0.2 & 0.18 & 3.34 & Accepted \\
\hline $\mathrm{H} 4$ & $\begin{array}{l}\text { Subjective norm } \rightarrow \\
\text { Entrepreneurial intention }\end{array}$ & 0.38 & 0.32 & 6.2 & Accepted \\
\hline
\end{tabular}


between variables (Hair Jr. et al., 2014). Table 3 (see appendix) shows the values of all the goodness of fit criteria, with scores higher than 0.9 (Hair Jr. et al., 2014). These results indicated that the empirical data matched the theoretical sample model proposed.

Table 4 shows the results of the hypotheses tests using a significance level of 0.05 and the yields on the values of the t-statistics, all of which were above 1.96. These results indicated the rejection of the null hypothesis, in other words, the alternative hypothesis was accepted (Hair Jr. et al., 2014). All the proposed hypotheses empirically supported and were based on the standardized scores solution, religiosity's influence on attitude had the greatest path score.

As shown in Table 5 (see appendix), the total influence from religiosity and the subjective norms intention was very high, at 0.83 . The effect of religiosity, both directly and indirectly, on the intention to behave, was combined with the effect of attitude, and the result was $0.33+$ $0.18=0.51$. This result also showed that the proposed theoretical model efficiently aids in the prediction of human behavior

\section{b. Rasch model results}

Person-item map

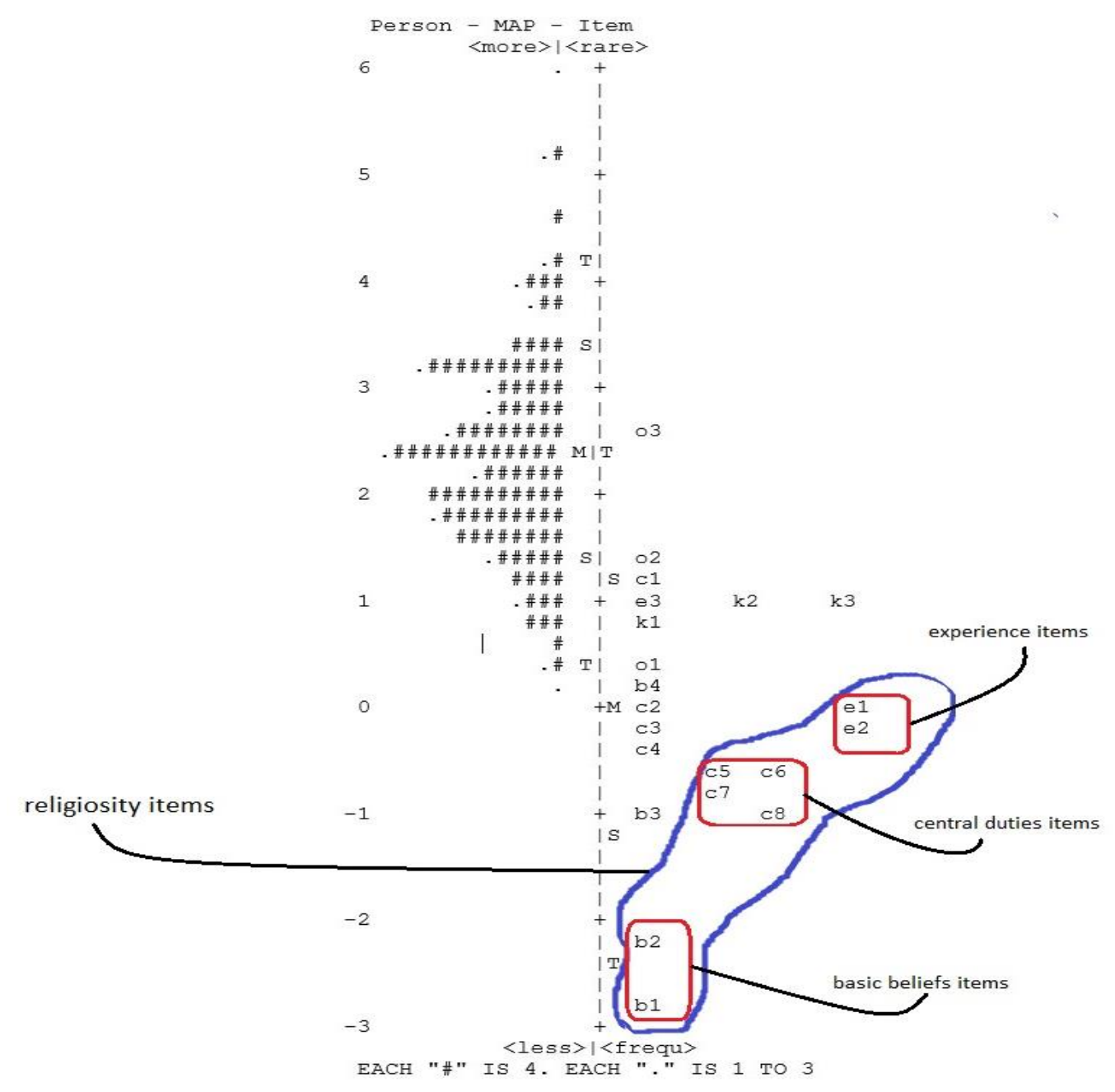

Figure 3 Persons-items map

Source: Data analyzed 
Figure 3 depicts the raw calibration of the logit measure between the respondents on the left side, and items on the right side. Responses and items inside the red lines are outliers based on the following formula: mean (M) plus/minus the standard deviation (S). For more detailed results, please see Table 6 and Table 7 (appendix). This map shows that the average respondents' ability to approve $(\mathrm{M}$ person $=$ 2.36) was higher than the mean item difficulty level $(\mathrm{M}$ item $=0)$. Items inside the blue line, i.e., b1, b2, c5, c6, c7, c8, e1, e2, are the items that make up the religiosity construct in the SEM's structural model. In general, the map shows that the level of religiosity of the respondents was exceptionally high compared to what can be measured by the items. Ideally, the person and items have the same mean values zero.

Visually, we declared o3 (a Muslim is not allowed to listen to music) was the item that was most difficult for respondents to agree on. Along with 03 , o2 (I avoid handshakes with people of the opposite sex), b2 (I'm sure Allah is close), b1 (I believe Allah exists) were outliers due to their position on the logit ruler which were higher/lower than average (M) plus/minus standard deviation ( $\mathrm{T}$ ). In particular, items inside the blue line, which in SEM were valid measures for the religiosity variable, in the Rasch model, b1 and b2 were easy to approve of, even for the respondent with the lowest religiosity, viz. no.43 with code 043fF6\#. It means b1 and b2 were unable to differentiate between the respondents, based on their religiosity.

\section{c. Validity and reliability}

Table 8 (see appendix) shows that the validity of the person was very satisfying because the INFIT MNSQ and OUTFIT MNSQ values were in the range of $0.5<\mathrm{MNSQ}<1.5$, namely 1.06 and 1.02. Likewise, the values for INFIT ZSTD and OUTFIT ZSTD were in the range of -2.0 $<$ ZSTD <2.0, i.e. 0.1 and -0.1 . This meant the quality of the respondents was excellent. In other words, the empirical data pattern fitted the ideal pattern proposed by the Rasch model. The same thing also happened to the instrument items, with the values of INFIT MNSQ 0.99 and OUTFIT MNSQ 1.02, and INFIT ZSTD -0.6 and OUTFIT ZSTD 0.0. Overall, the items on a religious scale had good validity. For the reliability of people, respondent no. 435 answered "very agree" to all the items. Therefore, he (number 435 , code $435 \mathrm{mS} 1 \#$ ) was declared an outlier. However, the reliability of this person, as part of a group (consisting of 435 people plus himself) was equally good, which was 0.83 .The item reliability score was 0.99 . The Cronbach's alpha value was 0.82 . In this study, the respondents and items had satisfactory reliability.

\section{d. Discussion}

In fulfilling the first research purpose, based on the verified extended TRA model in the context of blue-collar workers, we determined that religiosity affected entrepreneurial intentions both directly and indirectly. Slightly different from our first attempt (Wibowo, 2017) in the context of hijab-wearing behavior, which only received support for its indirect influence. Bluecollar workers' religiosity plays a crucial role in shaping a positive attitude toward entrepreneurial behavior, once they have the intention to start.

This finding supports our results in the context of wearing the hijab (Wibowo \& Masitoh, 2018). This support is in the form of verifying the direct influence of religiosity on attitudes and intentions. Nonetheless, our findings contradict Wibowo \& Masitoh (2018), who found no support for a mediating relationship between attitudes toward the 
influence of religiosity on intention. Some studies have only found a single influence (i.e., attitude not directly affecting the intention to behave; (Souiden \& Rani, 2015)(Wibowo, 2017)), or no influence on attitude (Syed. S. Alam et al., 2012). The results of this study are slightly different from Wibowo and Masitoh (2018), who found that attitudes are not related to behavior when the variable of religiosity directly affects both.

As for the influence of subjective norms on entrepreneurial intentions, the results of this study provide support for the argument that, in forming entrepreneurial intentions, social pressure from people who have an interest in the respondent had a significant influence. The effect of this pressure was lower (-0.01) than the effect of religiosity. Our findings support previous empirical findings in the context of software piracy (Aleassa et al., 2011)and travel to gaming destinations, e.g. Las Vegas (Al Jahwari, 2015). However, the results of this study contradict research in Turkey (Bektaş, 2011),despite having a similar model. It was likely that those with a professional background could distinguish and control perceptions regarding the social pressure they receive.

Therefore, the extended TRA model in this study proved to be reliable in predicting entrepreneurial intentions with the addition of religiosity. The test results of all the hypotheses supported the argument of the TRA expansion model in this study, paving the way for its use as an inter subjectively certifiable item (HUNT, 1991) in other contexts. Although SEM is an explanatory model, an adequate explanation has the potential to be a prediction, or vice versa (HUNT, 1991).

For the second research purpose, we incorporated the application of SEM and the Rasch model to gain additional prescriptive insights from the verified extended TRA model. Applying the person-item map analysis to religiosity showed us that the level of religiosity of the respondents was exceptionally high compared to what can be measured by the items. Our respondents likely held a social desirability bias, based on the means distance of persons measure to the items measure in persons-items map. Unfortunately, to verify this one by one is very difficult, because we did a paper-based selfadministered data collection. Future studies should note this.

Furthermore, we argue that the variation in the dependent variable, which indeed originates from the variation of the independent variables, can be better explained by providing an in-depth analysis of the variation of the independent variable. By analyzing critical independent variables -if more than one- we can provide a more precise explanation regarding the results of our hypotheses testing. In this study, the independent variable of concern was religiosity, which consisted of items: b1 (I believe Allah exists),b2 (I'm sure Allah is close),c8(I want to go on hajj), c7(I always pay zakat fitrah), c5 (I fasted in the month of Ramadan), c6 (I always try to eat halal food), e2 (I once felt guided by Allah when facing problems),e1 (I feel blessed by Allah). These items were arranged from the easiest to the most difficult to agree on. 


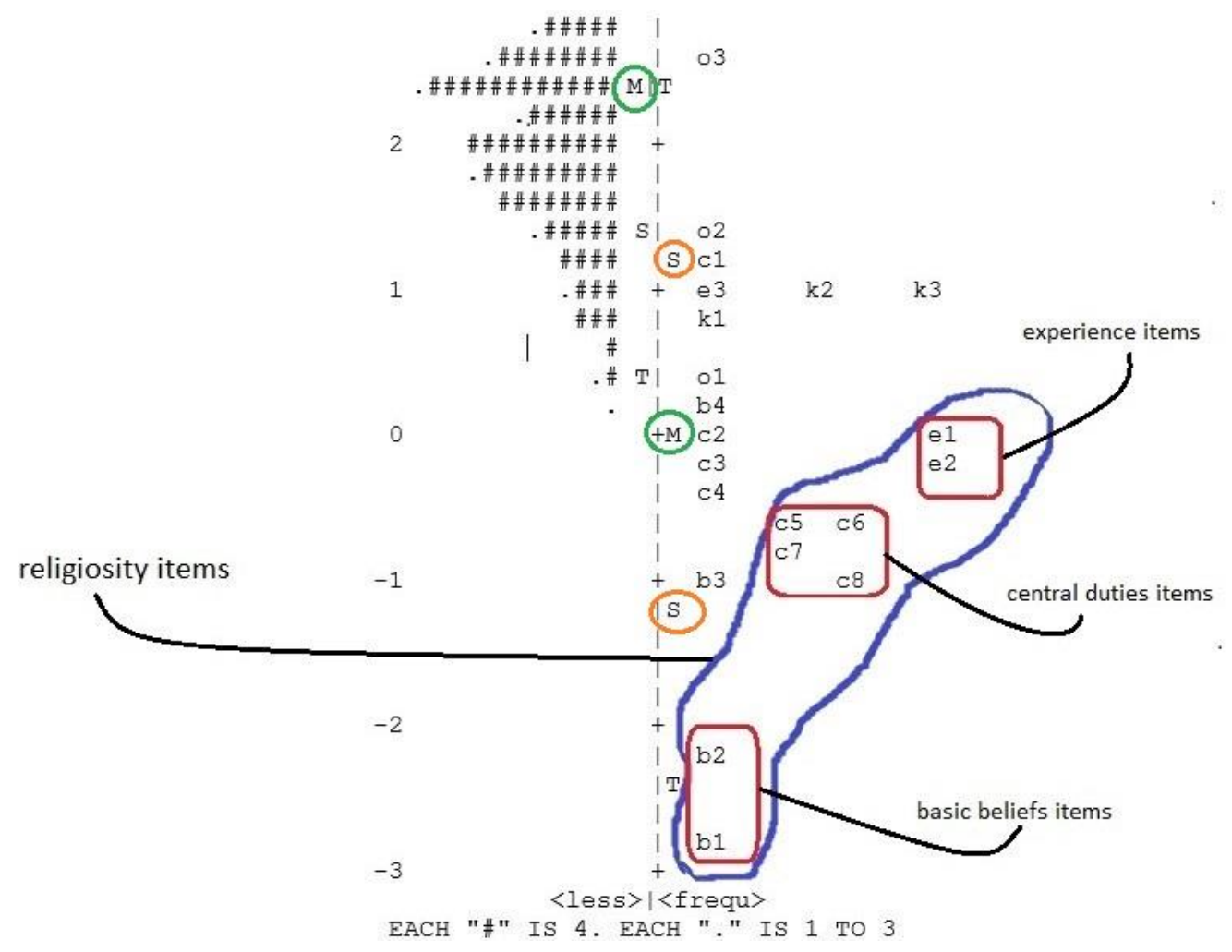

Figure 4 Cropped from figure 3

Source: Data calculated

Figure 4 shows that all the religiosity items in SEM were surrounded by a blue line. Then we see that the dimensions of experience, central tasks, and basic beliefs are grouped according to the level of difficulty in finding agreement about them. Remember, according to the Rasch model, items b1 and b2 were outliers because the position of the difficulty level was outside the standard deviation ( $\mathrm{S}$ with the orange circle). But in SEM after LVS was done, these items were the compilers of basic belief. A basic belief is a valid manifest variable representing religiosity along with central duties and experiences. We can state that the chosen items for the dimension of religiosity were, grouped according to the level of difficulty of agreement about them. This is why we used all the items of religiosity in the analysis by the Rasch model. In this way, we can find out which items, according to the SEM and the Rasch model, represent the validity of the latent variables.

We obtained high-value serendipitous results from combining the SEM and Rasch models. The LVS technique converts the dimensions of religiosity into the manifest variables of religiosity, meaning that there was a change in the shape and quality of the variations of a number of manifest variables into one dimension. However, the empirical evidence in Figure 4 shows that a decrease in the quality of the variation does not occur. Manifest variables which represented their dimensions were grouping well (have close distance) when the condition of this dimension in SEM was the manifest variable. This empirical evidence reinforces the validity of using the LVS technique when the SEM model is very complex. With these surprising findings, we are confident in stating that variations on the dependent variable in the SEM model can be 
explained better by explicating the independent variable, using the Rasch model. Our work opens a broad space for discussion and debate of the methods, ways of selecting independent variables, assumptions of the model, consistency of the researcher's position, measurement scale considerations, etc. However, we remain confident that the results of the SEM model make more sense, with additional insights from the Rasch model.

Becoming an entrepreneur after a long-time lag (as blue-collar workers are still working) would undoubtedly be a rationally chosen alternative as the TRA's assumption. Our findings provide sufficient empirical evidence to state that differences in the contextual and assumptive explanatory models were better explained using the Rasch model. The higher the religiosity of blue-collar workers, the higher the likelihood of their positive attitude toward entrepreneurial behavior while increasing their intention to become entrepreneurs

\section{CONCLUSION AND SUGGESTION}

Our findings proved that, in the context of blue-collar workers, religiosity has a significant influence on the formation of both attitude and entrepreneurial intention. Subjective norms also proved to influence blue-collar worker's entrepreneurial intentions. The extended TRA empirically proved to have satisfactory results in predicting the undoubtedly entrepreneurial intentions of blue-collar workers. We accomplished the intersubjectively certification for this model and encourage other researchers to do the same. We can also conclude that, based on the Rasch model's results, respondents in this study have a high level of religiosity concerning the scale items used. There is indeed a possibility that they experienced social desirability bias. This possibility is our explanation and cannot be verified by re- observation techniques because of our paperbased data collection procedure. With additional insights from the Rasch model, the SEM's test results became more transparent. In the context of blue-collar workers, the choice to become entrepreneurs, considering the time lag they will experience by still currently having a job, is very rational. This research opens discussions and debates related to the merging of the application of SEM and the Rasch model. Nevertheless, we believe that the development of such measurement techniques in behavioral science will be more precise and reliable. Regarding the interests of policymakers, the effect of religiosity on attitudes is greater than its effect on intention. They can use Islamic public figures, who are also entrepreneurs, to act as role models for blue-collar workers.

\section{Acknowledgement}

We would like to thank the Indonesian Ministry of Research and Technology and Higher Education of Republic of Indonesia for funding this research. We also thank the three reviewers and the proofreader, who reviewed and gave valuable suggestions to this article and made it suitable for international scientific consumption.

\section{REFERENCE}

Ahrold, T. K., Farmer, M., Trapnell, P. D., \& Meston, C. M. (2011). The Relationship Among Sexual Attitudes, Sexual Fantasy, and Religiosity. Journal of Sexual Behavior, 40(3), 619-630. https://doi.org/10.1007/s10508-010-9621-4

Ajzen, I. (2010). Constructing a theory of planned behavior questionnaire. Biofeedback and Selfregulation, 17, 1-7. Retrieved from

https://people.umass.edu/aizen/pdf/tpb.meas urement.pdf

Ajzen, I. (2012). Martin Fishbein's Legacy. The ANNALS of the American Academy of 
Political and Social Science, 640(1), 11-27. https://doi.org/10.1177/0002716211423363

Al-Bukhari No. 590. (n.d.). Sahih Bukhari, Chapter: Loans, Payment of Loans, Freezing of Property and Bankruptcy. Retrieved from https://ahadith.co.uk/permalink-hadith-5770

Al Jahwari, D. S. (2015). An Integrative Model of Muslim Students' Religiosity and Travelling Behavior to Gaming Destinations (University of South Carolina). Retrieved from https://core.ac.uk/download/pdf/217680853. pdf

Alam, Syed. S., Janor, H., Zanariah, W., C. A. C., \& Ahsan, M. N. (2012). Is Religiosity an Impportant Foctor in Influencing the ntention to Undertake Islamic Home Financing in Klang Valley?? World Applied Science Journal, 19(7), 1030-1041.

Alam, Syed Shah, Janor, H., Aniza, C., \& Wel, C. (2012). Is Religiosity an Important Factor in Influencing the Intention to Undertake Islamic Home Financing in Klang Valley? World Applied Science Journal, 19(7), 1030-1041.

https://doi.org/10.5829/idosi.wasj.2012.19.0 7.392

Aleassa, H., Pearson, J. M., \& McClurg, S. (2011). Investigating Software Piracy in Jordan: An Extension of the Theory of Reasoned Action. Journal of Business Ethics, 98(4), 663-676. https://doi.org/10.1007/s10551-010-0645-4

Azwar, S. (2013). Sikap Manusia Teori dan Pengukurannya (2nd ed.). Yogyakarta: Pustaka Pelajar.

Barkan, S. E. (2014). Gender and Abortion Attitudes: Religiosity as a Suppressor Variable. Public Opinion Quarterly, 78(4), 940-950.

https://doi.org/10.1093/poq/nfu047

Bektaş, F. (2011). Entrepreneurial Intentions of Turkish University Students. International Journal of Arts \& Sciences, 4(8), 167-181.
Bond, T. G., \& Fox, C. M. (2015). Applying the Rasch Model Fundamental Measurement in the Human Sciences. In Intergovernmental Panel on Climate Change (Ed.), Climate Change 2013 - The Physical Science Basis (3rd ed.). New York: Routledge.

Bogoviz, A. V., Osipov, V. S., Chistyakova, M. K., \& Borisov, M. Y. (2019). Comparative Analysis of Formation of Industry 4.0 in Developed and Developing Countries. In E. G. Popkova, Y. V. Ragulina, \& A. V. Bogoviz (Eds.), Industrial Revolution of the 21 st Century, Studies in Systems, Decision and Control 169, (pp. 155-164). https://doi.org/10.1007/978-3-319-943107_15

El-Menouar, Y. (2014). The Five Dimensions of Muslim Religiosity. Results of an Empirical Study. Method, Data, Analyses, 8(1), 53-78. https://doi.org/10.12758/mda.2014.003

Fishbein, M., \& Ajzen, I. (2010). Predicting and Changing Behavior. https://doi.org/10.4324/9780203838020

Fishbein, M., \& Ajzen, I. (1975a). Attitude formation. In Belief, Attitude, Intention, and Behavior, An Introduction to Theory and Research (pp. 216-287).

https://doi.org/10.1016/B978-0-12-3750006.00041-0

Fishbein, M., \& Ajzen, I. (1975b). Attitude Theory. In Belief, Attitude, Intention, and Behavior, An Introduction to Theory and Research (pp. 21-52). https://doi.org/10.1016/B978-0-12-3750006.00041-0

Grande, T. (2015). Identifying Multivariate Outliers with Mahalanobis Distance in SPSS. Retrieved from www.youtube.com website:

https://www.youtube.com/watch?v=AXLA X6r5JgE

Gullatte, M. (2006). The Influence of Spirituality and Religiosity on Breast Cancer Screening Delay in African American Women: Application of Theory of Reasoned Action and Planned Behavior (TRA/TPB). ABNF Journal, 17(2), 89. 
Hair Jr., J. F., Black, W. C., Babin, B. J., \& Anderson, R. E. (2014). Multivariate Data Analysis. In Pearson new international edition (7th ed.). Retrieved from www.pearsoned.co.uk

Holdcroft, B. (2006). What is Religiosity? Catholic Education: A Journal of Inquiry and Practice, 10(1), 89-103.

Hunt, S. D. (1991). Modern Marketing Theory: Critical Issues In The Philosophy of Marketing Science (T. E. Shaffer, Ed.). Cincinnati: South-Western Publishing Co.

Johnson, B. R., Jang, S. J., Larson, D. B., \& DE LI, S. (2001). Does Adolescent Religious Commitment Matter? A Reexamination of the Effects of Religiosity on Delinquency. Journal of Research in Crime and Delinquency, 38(1), 22-44. https://doi.org/10.1177/0022427801038001 002

Khalek, A. A., \& Ismail, S. H. S. (2015). Why Are We Eating Halal - Using the Theory of Planned Behavior in Predicting Halal Food Consumption among Generation $\mathrm{Y}$ in Malaysia. International Journal of Social Science and Humanity, 5(7), 608-612. https://doi.org/10.7763/IJSSH.2015.V5.526

Lada, S., Harvey Tanakinjal, G., \& Amin, H. (2009). Predicting intention to choose halal products using theory of reasoned action. International Journal of Islamic and Middle Eastern Finance and Management, 2(1), 66-76.

https://doi.org/10.1108/1753839091094627 6

Mahudin, N. D. M., Noor, N. M., Dzulkifli, M. A., \& Janon, S. N. (2016). Religiosity among Muslims : A Scale Development and Validation Study. Makara Hubs-Asia, 20(2), 109-120.

https://doi.org/10.7454/mssh.v20i2.3492

McKenzie, D. (2012). Relationship between Religiosity, Violent Behavior and Gang Activity among Economically Disadvantaged Adolescents (University of Alabama). Retrieved from https://pqdtopen.proquest.com/doc/1287057

\section{9.html?FMT=ABS}

Nawawi No. 2. (n.d.). An-Nawawi's 40 hadith the forty hadith. Retrieved from https://ahadith.co.uk/nawawis40hadith.php

Pozdnyakova, U. A., Golikov, V. V., Peters, I. A., \& Morozova, I. A. (2019). Genesis of the Revolutionary Transition to Industry 4.0 in the 21st Century and Overview of Previous Industrial Revolutions. In E. G. Popkova, Y. V. Ragulina, \& A. V. Bogoviz (Eds.), Industrial Revolution ofthe 21st Century, Studies in Systems, Decision and Control 169, (pp. 11-19).

https://doi.org/10.1007/978-3-319-943107_2

Salzberger, T., \& Koller, M. (2013). Towards a new paradigm of measurement in marketing. Journal of Business Research, 66(9), 1307-1317.

https://doi.org/10.1016/j.jbusres.2012.02.03 0

Schouten, C. M. D. D., \& Graafland, J. (2014). Religiosity, CSR Attitudes, and CSR Behavior: An Empirical Study of Executives' Religiosity and CSR. Journal of Business Ethics, 123, 437-459. https://doi.org/10.1007/s10551-013-1847-3

Shakona, M. Y. (2013). The Influence of Religiosity on the Intention of United States Muslim Tourists to Choose a Shariah Compliant Hotel (Graduate School of Clemson University). Retrieved from http://search.proquest.com.ezaccess.library. uitm.edu.my/docview/1499232994?accounti $\mathrm{d}=42518$

Slater, W. E., Hall, T. W., \& Edwards, K. J. (2001). Measuring religion and spirituality: where we are and where are we going? Journal of Psychology and Theology, 29(1), 4-21.

Souiden, N., \& Rani, M. (2015). Consumer attitudes and purchase intentions toward Islamic banks: the influence of religiosity. International Journal of Bank Marketing, 33(2), 143-161. https://doi.org/10.1108/IJBM-10-2013-0115 
Sukhodolov, Y. A. (2019). The Notion, Essence, and Peculiarities of Industry 4.0 as a Sphere of Industry. In E. G. Popkova, Y. V. Ragulina, \& A. V. Bogoviz (Eds.), Industrial Revolution ofthe 21st Century, Studies in Systems, Decision and Control 169, (pp. 3-10).

https://doi.org/10.1007/978-3-319-943107_1

Sumintono, B., \& Widhiarso, W. (2014). Aplikasi Model Rasch untuk Penelitian Ilmu-Ilmu Sosial (2nd ed.; B. Trim, Ed.). Retrieved from https://www.researchgate.net/publication/26 8688933_Aplikasi_Model_Rasch_untuk_Pe nelitian_Ilmu-Ilmu_Sosial_edisi_revisi

Sumintono, B., \& Widhiarso, W. (2016). Aplikasi Model Rasch untuk Penelitian Ilmu-Ilmu Sosial (edisi revisi). In Aplikasi Model Rasch untuk Penelitian Ilmu-Ilmu Sosia.

Wibowo, H. A. (2017). The Effects of Indonesia Female Religiosity on Hijab - Wearing Behavior: An Extended of Theory of Reasoned Action. International Review of Management and Business Research, 6(3), 1040-1050.

\section{https://doi.org/10.17605/osf.io/r4gjc}

Wibowo, H. A., \& Masitoh, M. R. (2018). Measuring religiosity and its effects on attitude and intention to wear a hijab: Revalidating the scale. In Badri Munir Sukoco, Rahmat Heru Setianto, Nidya Ayu Arina, Ade Gafar Abdullah, \& R. H. Asep Bayu Dani Nandiyanto (Eds.), Increasing Management Relevance and Competitiveness (1st ed., p. 538). https://doi.org/10.1201/9781351241892-44

Wijanto, S. H. (2008). Structural Equation Modeling dengan LISREL 8.8 Konsep \& Tutorial (1st ed.). Yogyakarta: Graha Ilmu

Yoon, C. (2011). Theory of Planned Behavior and Ethics Theory in Digital Piracy: An Integrated Model. Journal of Business Ethics, 100(3), 405-417. https://doi.org/10.1007/s10551-010-0687-7 


\section{Appendix}

A. Preliminary Analysis: Factor Analysis (SPSS software)

\begin{tabular}{llr}
\hline \multicolumn{3}{c}{ KMO and Bartlett's Test } \\
\hline $\begin{array}{l}\text { Kaiser-Meyer-Olkin Measure of Sampling } \\
\text { Adequacy. }\end{array}$ & 0.839 \\
\hline Bartlett's Test of & Approx. Chi- \\
Sphericity & Square & 585 \\
& & 1.2 \\
\cline { 2 - 3 } & df & 63 \\
\cline { 2 - 3 } & Sig. & 465 \\
\hline
\end{tabular}

Source: Data analyzed

\begin{tabular}{|c|c|c|c|c|c|c|c|c|}
\hline \multicolumn{9}{|c|}{ Rotated Component Matrix ${ }^{a}$} \\
\hline & \multicolumn{8}{|c|}{ Component } \\
\hline & 1 & 2 & 3 & 4 & 5 & 6 & 7 & 8 \\
\hline b1 & & & & & & 0.837 & & \\
\hline b2 & & & & & & 0.853 & & \\
\hline b3 & & & & & & 0.510 & & \\
\hline c3 & & & & & & & & 0.794 \\
\hline $\mathrm{c} 4$ & & & & & & & & 0.686 \\
\hline $\mathrm{c} 5$ & & & & 0.546 & & & & \\
\hline c6 & & & & 0.738 & & & & \\
\hline c7 & & & & 0.667 & & & & \\
\hline $\mathrm{c} 8$ & & & & 0.699 & & & & \\
\hline e1 & & & & & & & 0.672 & \\
\hline e2 & & & & & & & 0.665 & \\
\hline e3 & & & & & & & 0.727 & \\
\hline k1 & & & & & 0.672 & & & \\
\hline $\mathrm{k} 2$ & & & & & 0.799 & & & \\
\hline k3 & & & & & 0.807 & & & \\
\hline o1 & & & & & 0.552 & & & \\
\hline o2 & & & & & 0.545 & & & \\
\hline s1 & & & 0.666 & & & & & \\
\hline s2 & & & 0.765 & & & & & \\
\hline s3 & & & 0.702 & & & & & \\
\hline s4 & & & 0.668 & & & & & \\
\hline s5 & & & 0.628 & & & & & \\
\hline n1 & 0.626 & & & & & & & \\
\hline $\mathrm{n} 2$ & 0.844 & & & & & & & \\
\hline n3 & 0.788 & & & & & & & \\
\hline $\mathrm{n} 4$ & 0.813 & & & & & & & \\
\hline n5 & 0.602 & & & & & & & \\
\hline i1 & & 0.812 & & & & & & \\
\hline i2 & & 0.874 & & & & & & \\
\hline i3 & & 0.868 & & & & & & \\
\hline i4 & & 0.716 & & & & & & \\
\hline
\end{tabular}


Extraction Method: Principal Component Analysis.

Rotation Method: Varimax with Kaiser Normalization. ${ }^{a}$

a. Rotation converged in 9 iterations.

Source: Data analyzed

\section{B. Structural Equation Modelling results (LISREL 8.54 software)}

Table 1. Convergent Validity \& Reliability

\begin{tabular}{lccccc}
\hline \multicolumn{1}{c}{ Latent variables } & $\begin{array}{c}\text { Manifest } \\
\text { variables }\end{array}$ & SLF & error & CR & AVE \\
\hline \multirow{3}{*}{ Religiosity } & Basic & 0.57 & 0.68 & & \\
& Cendut & 0.86 & 0.25 & 0.73 & 0.48 \\
& Exprn & 0.61 & 0.63 & & \\
Attitudes & $\mathrm{s} 1$ & 0.7 & 0.51 & & \\
& $\mathrm{~s} 2$ & 0.88 & 0.22 & 0.76 & 0.52 \\
& $\mathrm{~s} 4$ & 0.54 & 0.71 & & \\
Subjective norms & $\mathrm{n} 1$ & 0.66 & 0.56 & & \\
& $\mathrm{n} 2$ & 0.81 & 0.34 & & \\
& $\mathrm{n} 3$ & 0.79 & 0.37 & 0.85 & 0.54 \\
& $\mathrm{n} 4$ & 0.76 & 0.43 & & \\
Entrep. intention & $\mathrm{n} 5$ & 0.64 & 0.59 & & \\
& $\mathrm{i} 1$ & 0.8 & 0.37 & & \\
& $\mathrm{i} 2$ & 0.94 & 0.11 & 0.91 & 0.77 \\
& $\mathrm{i} 4$ & 0.89 & 0.21 & & \\
\hline
\end{tabular}

Source: Data analyzed

Table 2. Discriminant Validity

\begin{tabular}{ccccc}
\hline Variables & Attitude & Intention & Religiosity & Sub. Norm \\
\hline Attitude & $\mathbf{0 . 5 2}$ & & & \\
Intention & 0.19 & $\mathbf{0 . 7 7}$ & & \\
Religiosity & 0.14 & 0.14 & $\mathbf{0 . 4 8}$ & \\
Sub. Norm & 0.28 & 0.21 & 0.04 & $\mathbf{0 . 5 4}$ \\
\hline
\end{tabular}

Source: Data analyzed

Table 3. Goodness of Fit

\begin{tabular}{cc}
\hline RMSEA & 0.076 \\
NFI & 0.95 \\
NNFI & 0.95 \\
CFI & 0.96 \\
IFI & 0.96 \\
RFI & 0.93 \\
GFI & 0.92 \\
\hline Source: Data analyzed &
\end{tabular}

Source: Data analyzed 
Table 4. Hypothesistest results

\begin{tabular}{cccccc}
\hline Hypothesis & Path & Estimate & $\begin{array}{c}\text { Std. } \\
\text { Solution }\end{array}$ & t stats. & Decision \\
\hline $\mathrm{H} 1$ & $\begin{array}{c}\text { Religiosity } \rightarrow \text { Entrepreneural } \\
\text { intention }\end{array}$ & 0.3 & 0.25 & 4.16 & Accepted \\
$\mathrm{H} 2$ & $\begin{array}{c}\text { Religiosity } \rightarrow \text { attitude } \\
\text { Attitude } \rightarrow \text { Entrepreneurial } \\
\text { intention }\end{array}$ & 0.46 & 0.42 & 6.66 & Accepted \\
$\mathrm{H} 3$ & $\begin{array}{c}\text { Subjective norm } \rightarrow \\
\text { Entrepreneurial intention }\end{array}$ & 0.38 & 0.32 & 6.2 & Accepted \\
\hline
\end{tabular}

Source: Data analyzed

Table 5. Total influence todependent variable

\begin{tabular}{cccccc}
\hline \multirow{2}{*}{ No. } & & \multicolumn{2}{c}{ Direct influence to } & Indirect influence to & Total influence \\
\cline { 3 - 6 } & Variables & Attitude & Intention & Intention & Intention \\
\hline 1 & Religiosity & 0.42 & 0.25 & 0.08 & $\mathbf{0 . 3 3}$ \\
2 & Attitude & & 0.18 & & $\mathbf{0 . 1 8}$ \\
3 & Sub. norms & & 0.32 & & $\mathbf{0 . 3 2}$ \\
\hline & & & & $\mathbf{0 . 8 3}$ \\
\hline
\end{tabular}

Source: Data analyze

\section{Rasch Model results (WINSTEP 3.73)}

Table 6. Person measure order

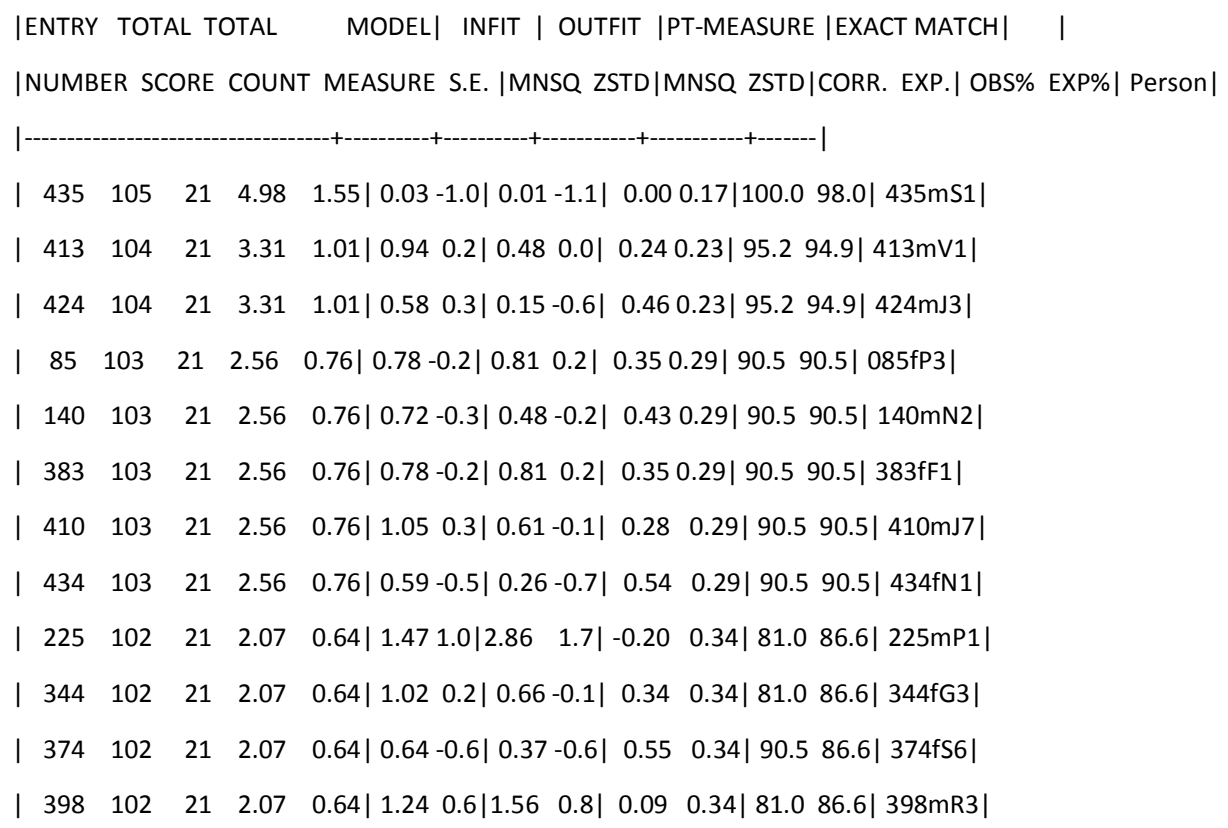




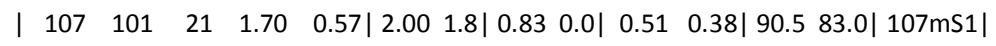

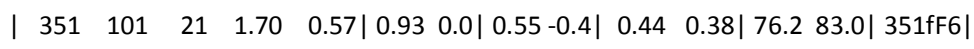

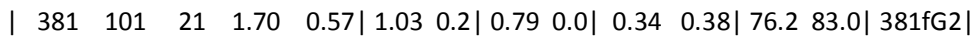

| $414 \quad 101 \quad 21 \quad 1.70 \quad 0.57|0.65-0.7| 0.47-0.6|0.56 \quad 0.38| 85.7 \quad 83.0|414 f N 3|$

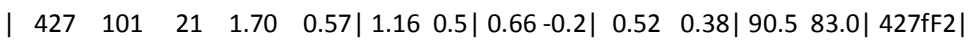

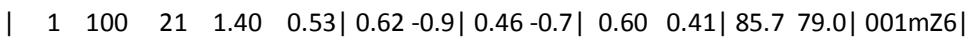

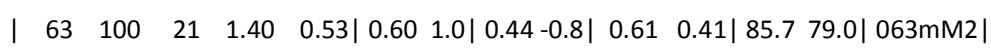

| \begin{tabular}{llllllll|ll|}
231 & 100 & 21 & 1.40 & $0.53 \mid 1.55$ & $1.3 \mid 1.74$ & $1.1 \mid$ & -0.08 & $0.41 \mid 66.7$ & $79.0|231 \mathrm{fl3}|$
\end{tabular}

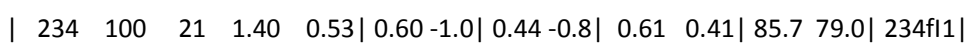

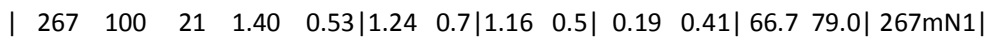

| $\begin{array}{llllllllll}345 & 100 & 21 & 1.40 & 0.53 \mid 1.25 & 0.7 \mid 1.30 & 0.6 \mid & 0.16 & 0.41 \mid 66.7 & 79.0 \mid 345 \mathrm{mG} 3\end{array}$

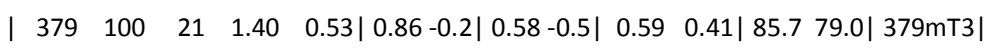

| $397 \quad 10021 \quad 1.40 \quad 0.53|0.53-1.2| 0.38-1.0|0.650 .41| 85.7$ 79.0| 397fF6 |

| $403 \quad 100 \quad 21 \quad 1.40 \quad 0.53|0.67-0.7| 0.53-0.6|0.56 \quad 0.41| 76.2$ 79.0| 403fl7|

\begin{tabular}{llllllllll|}
4 & 412 & 100 & 21 & 1.40 & $0.53|0.86-0.2| 0.57-0.5 \mid$ & 0.60 & $0.41 \mid 85.7$ & $79.0 \mid 412 \mathrm{fS} 6$
\end{tabular} \mid

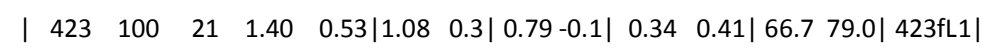

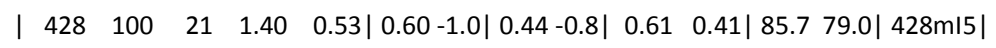

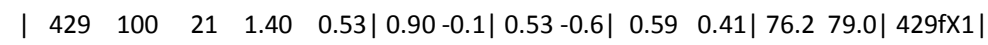

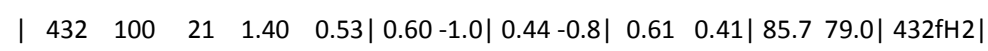

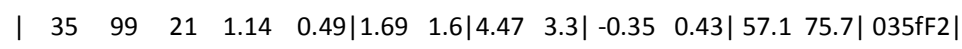

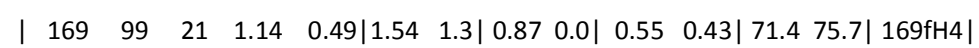

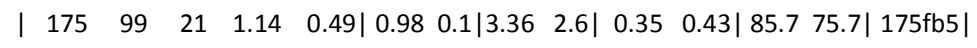

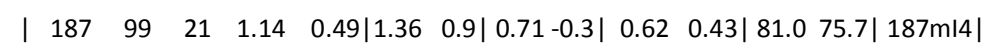

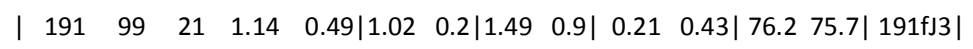

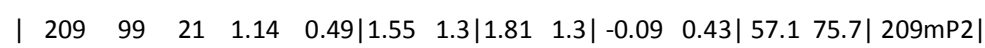

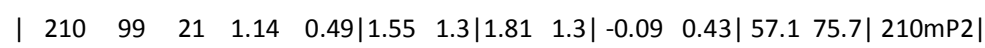

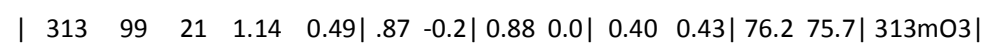

| \begin{tabular}{lllllll|lll|ll|}
385 & 99 & 21 & 1.14 & $0.49 \mid 1.73$ & $1.6 \mid$ & 0.90 & $0.1 \mid$ & 0.61 & $0.43 \mid$ & 90.5 & $75.7|385 f| 2 \mid$
\end{tabular}

\begin{tabular}{llllllllll|lll|}
\hline & 58 & 98 & 21 & 0.91 & $0.46 \mid 2.30$ & $2.6 \mid 2.82$ & $2.4 \mid$ & 0.00 & $0.45 \mid$ & 52.4 & $72.2 \mid$ & $058 m F 2 \mid$
\end{tabular}

\begin{tabular}{lllllllll|lll|}
77 & 98 & 21 & 0.91 & $0.46 \mid 1.50$ & $1.3 \mid 2.50$ & $2.1 \mid$ & -0.09 & $0.45 \mid$ & 47.6 & $72.2 \mid$ & $077 m M 3$
\end{tabular} \mid

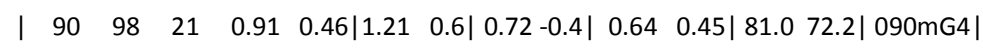

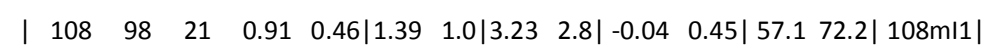

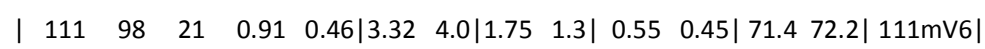

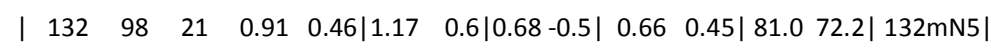

| $\begin{array}{lllllllllll}166 & 98 & 21 & 0.91 & 0.46 \mid 1.79 & 1.8 \mid 2.18 & 1.8 \mid & -0.29 & 0.45 \mid 38.1 & 72.2 \mid & 166 m F 1\end{array} \mid$

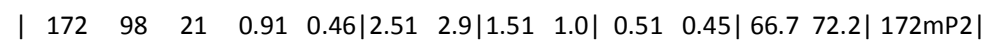

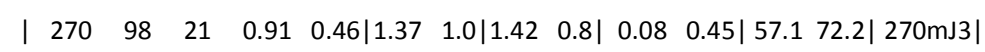

$\begin{array}{llllllllllll} & 304 & 98 & 21 & 0.91 & 0.46 \mid 1.60 & 1.5 \mid 1.89 & 1.5 \mid & -0.13 & 0.45 \mid & 47.6 & 72.2 \mid 304 f H 2\end{array} \mid$

| $\begin{array}{lllllllllllll}309 & 98 & 21 & 0.91 & 0.46 \mid 1.18 & 0.6 \mid 1.14 & 0.4 \mid & 0.23 & 0.45 \mid & 57.1 & 72.2 \mid 309 \mathrm{~m} / 2\end{array}$

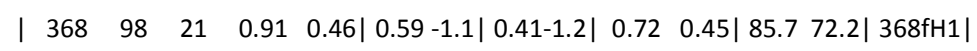

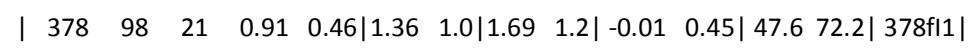

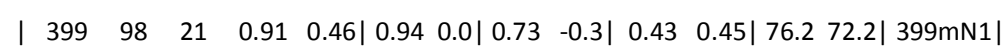




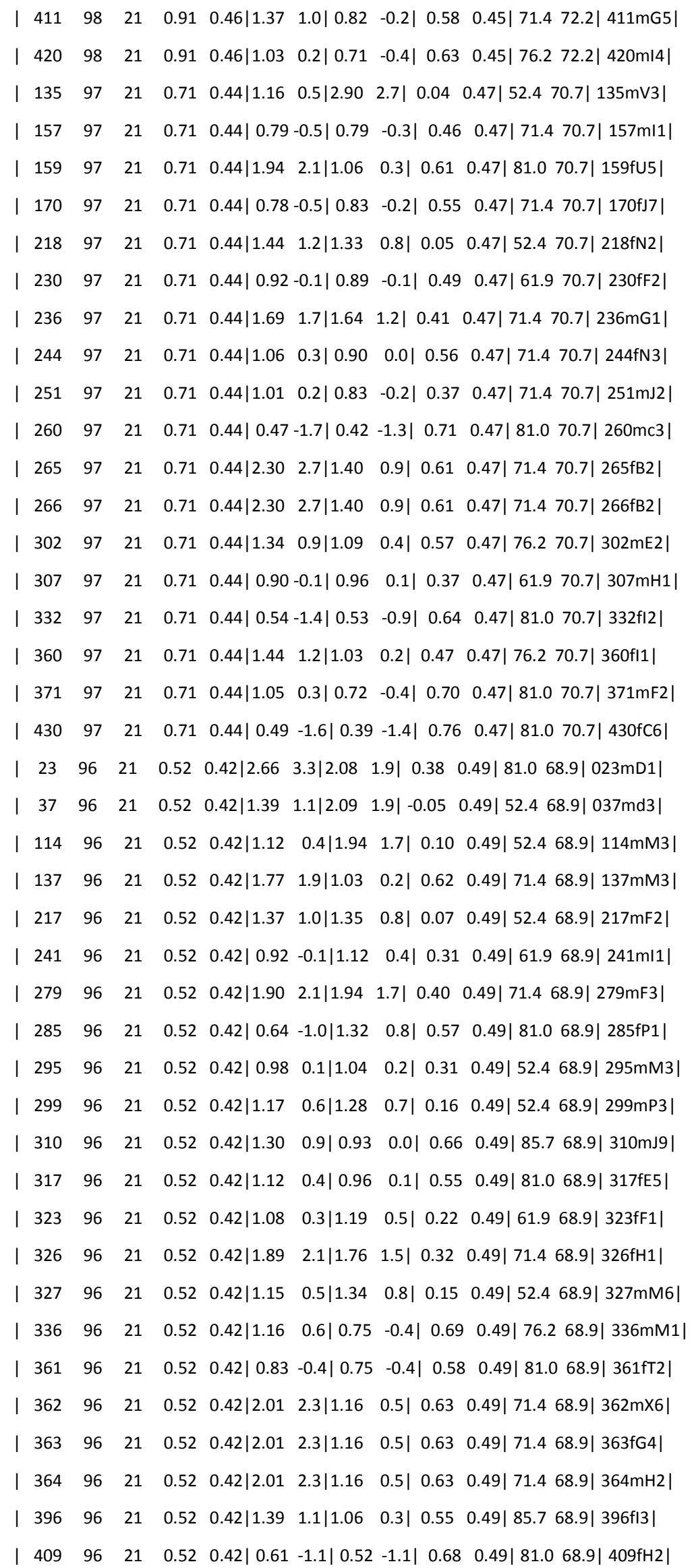




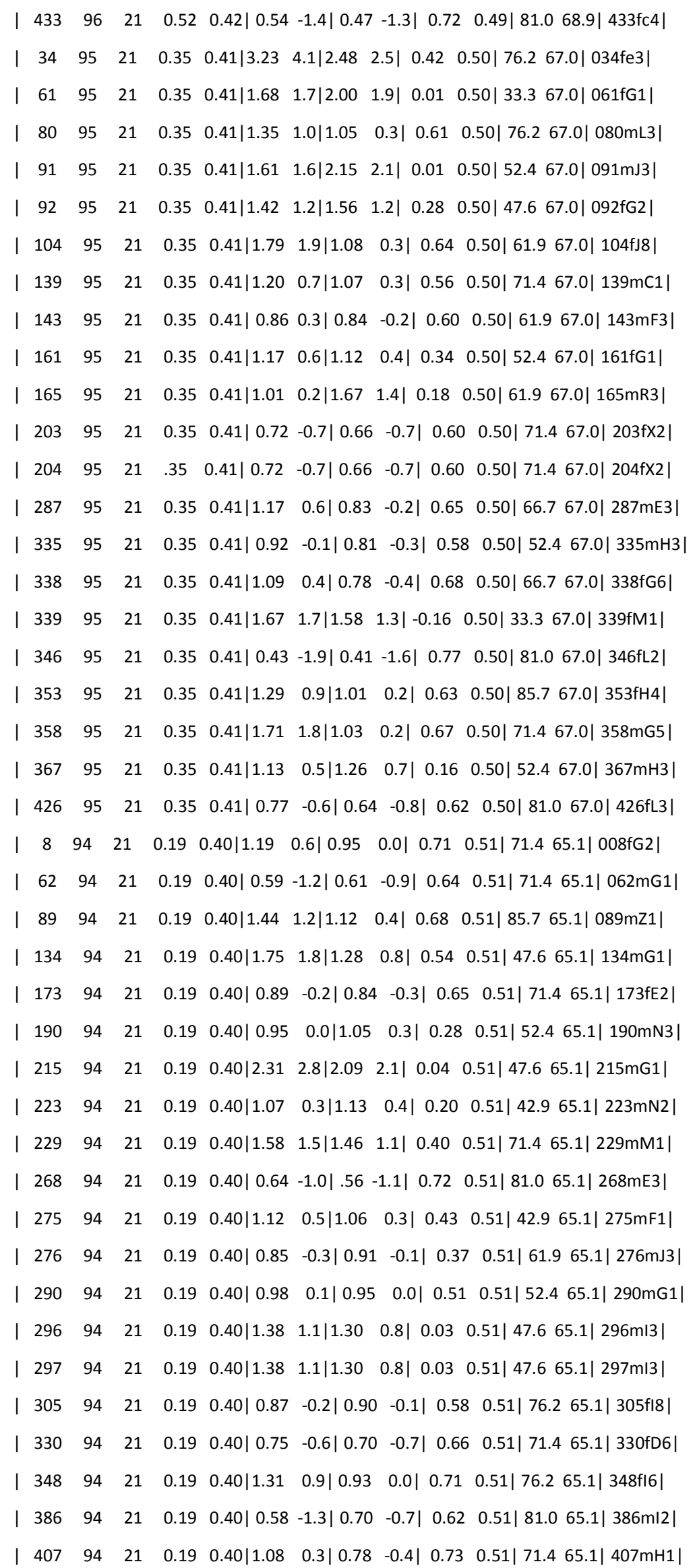




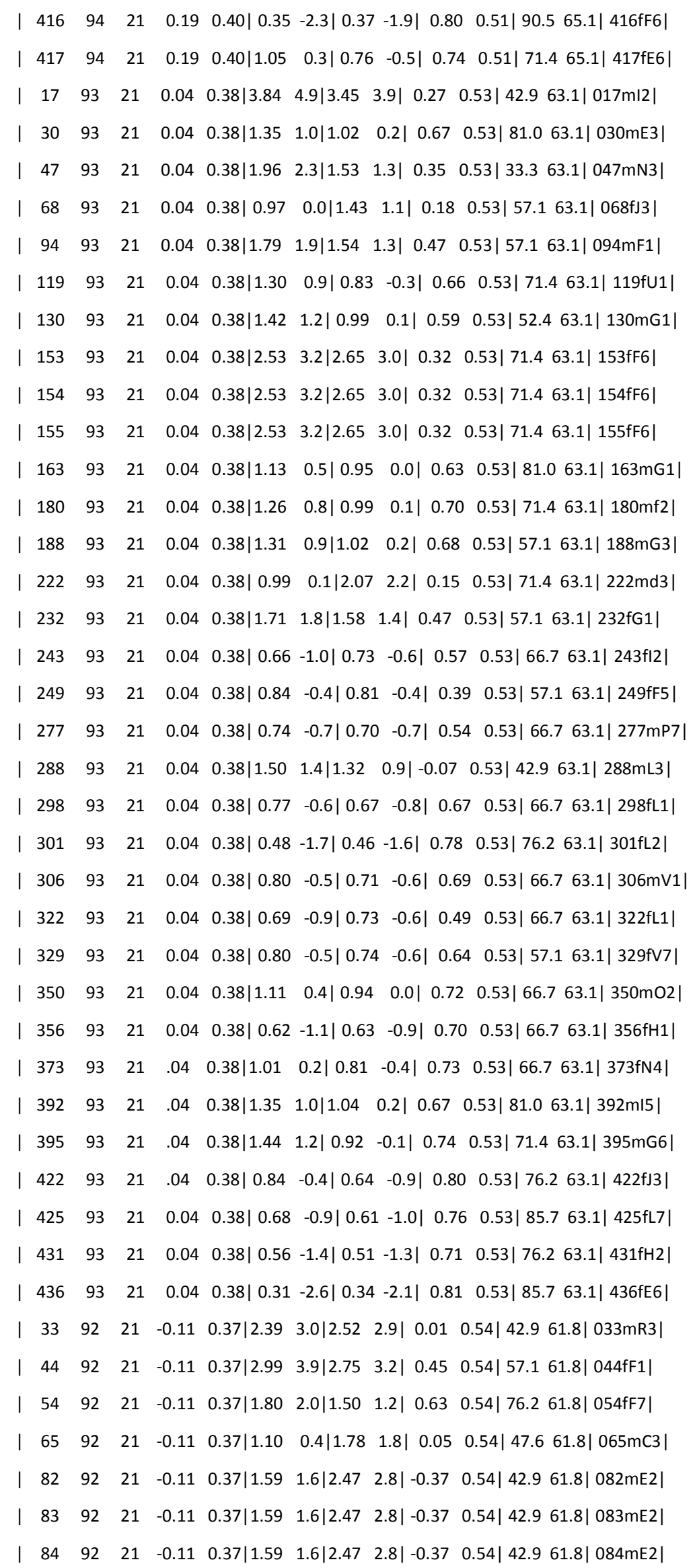




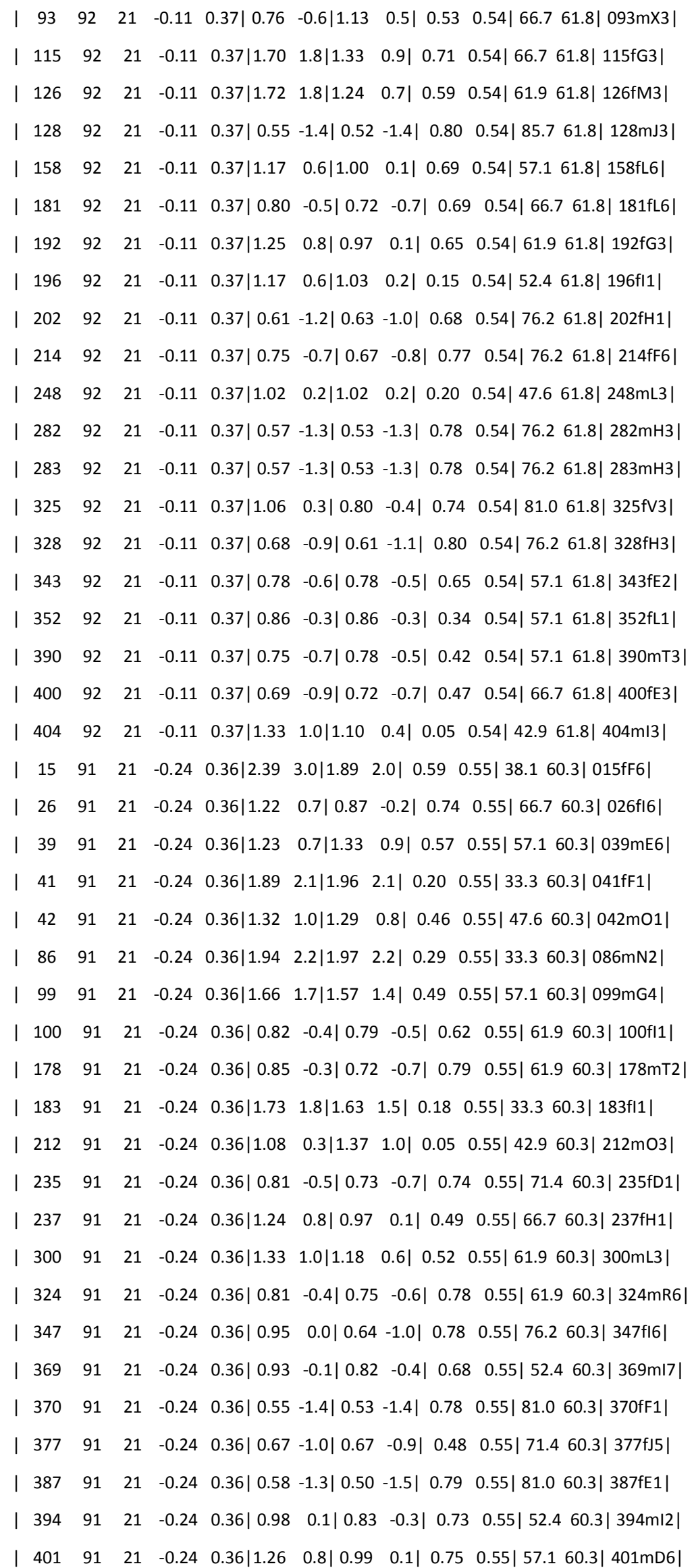




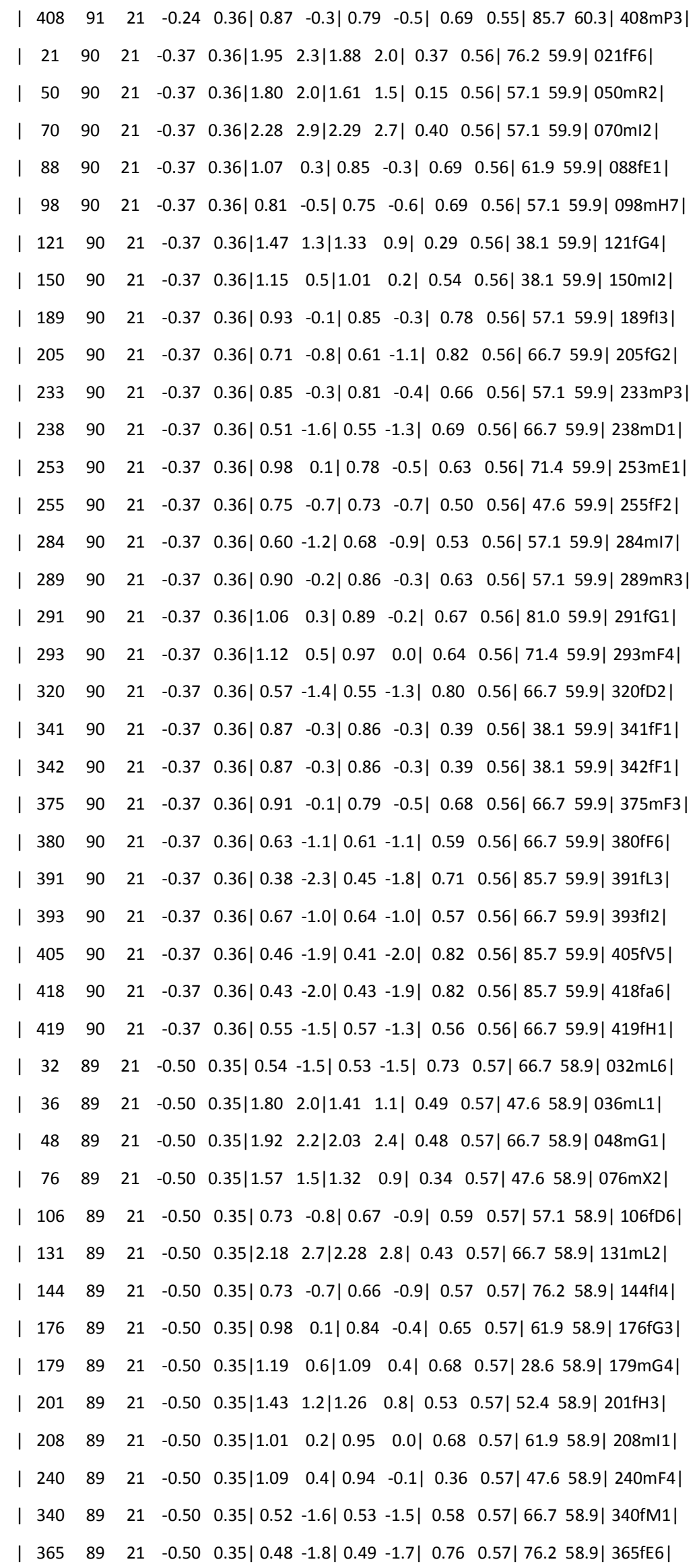




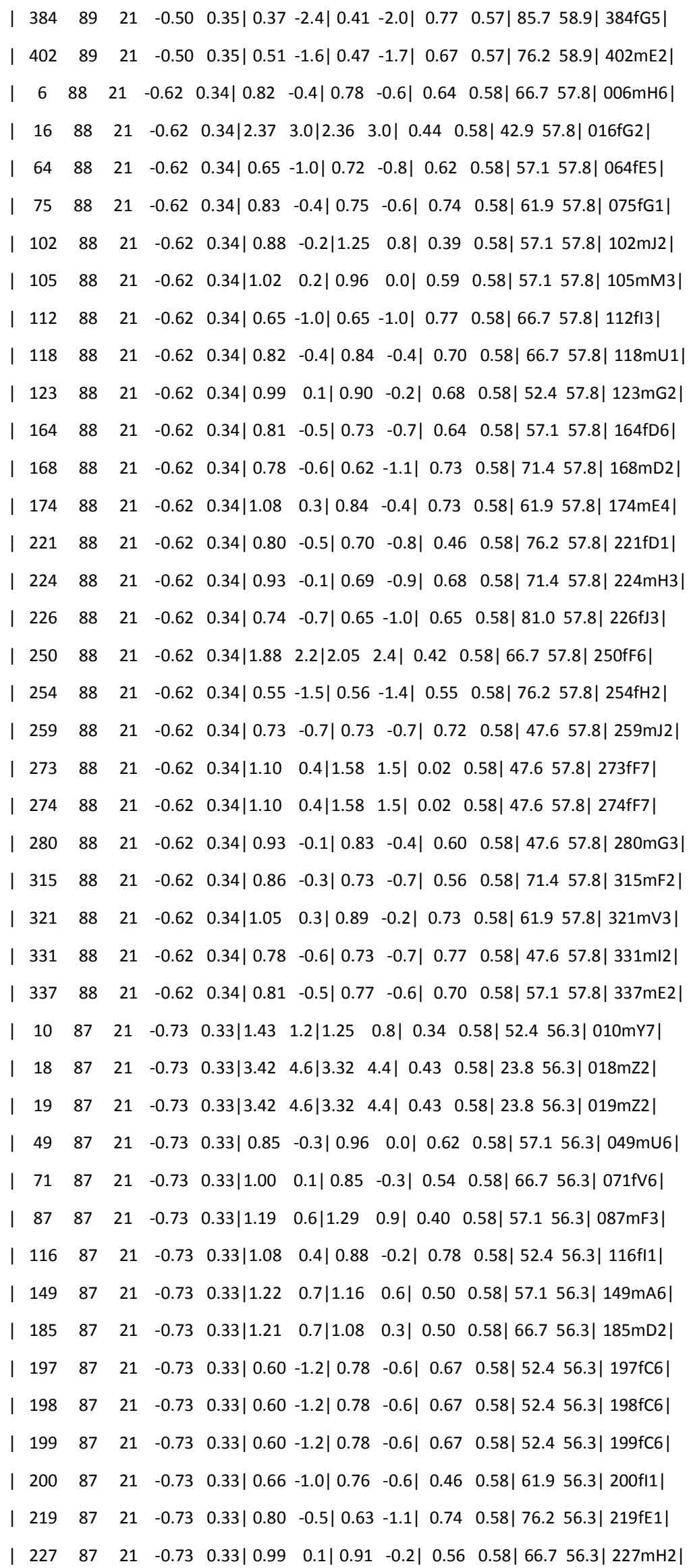




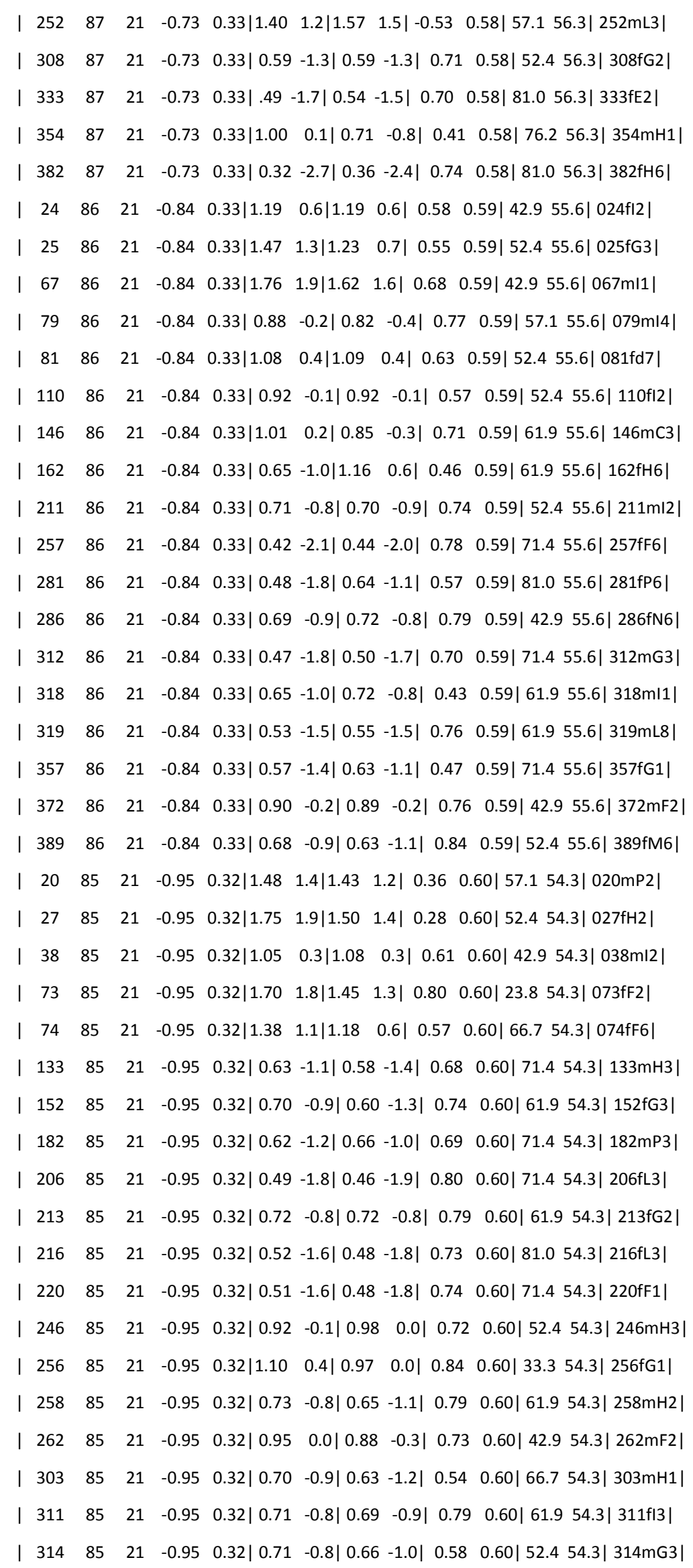




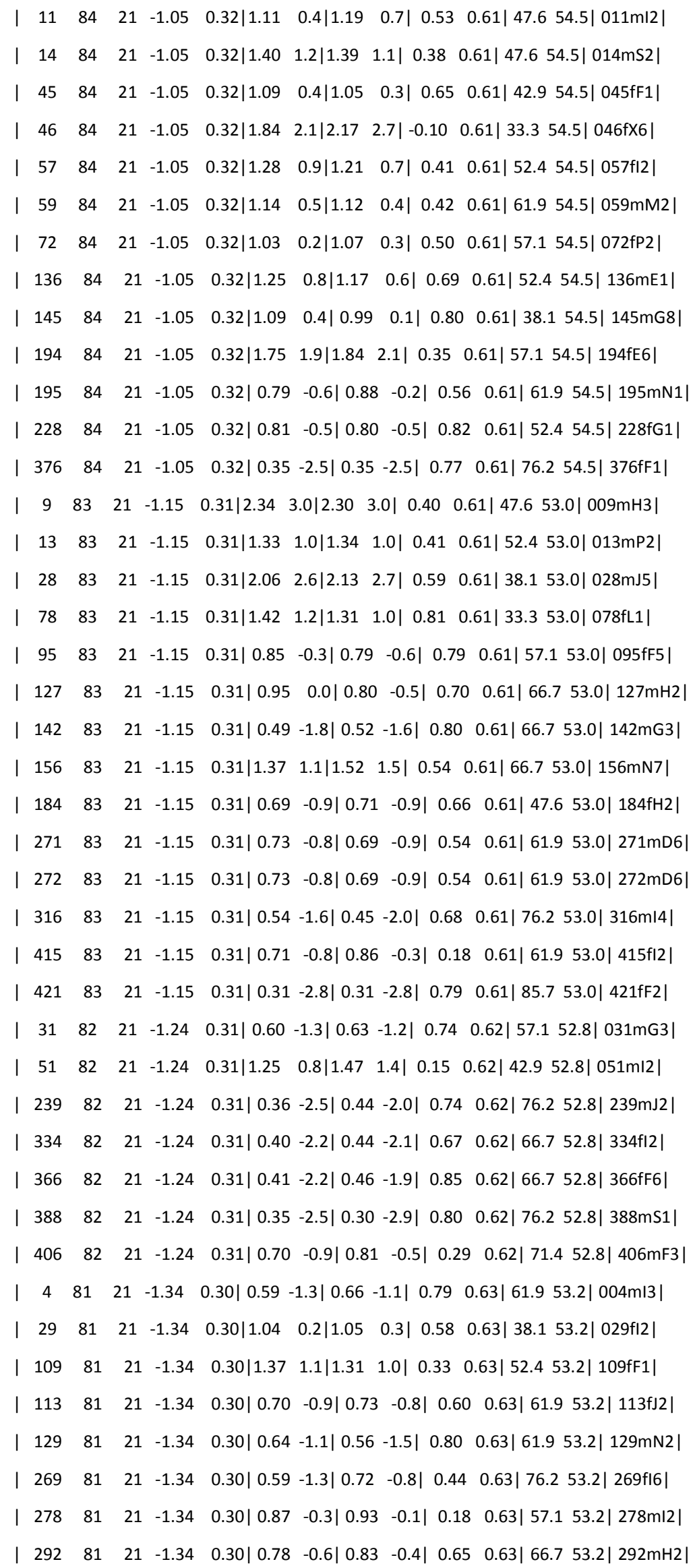




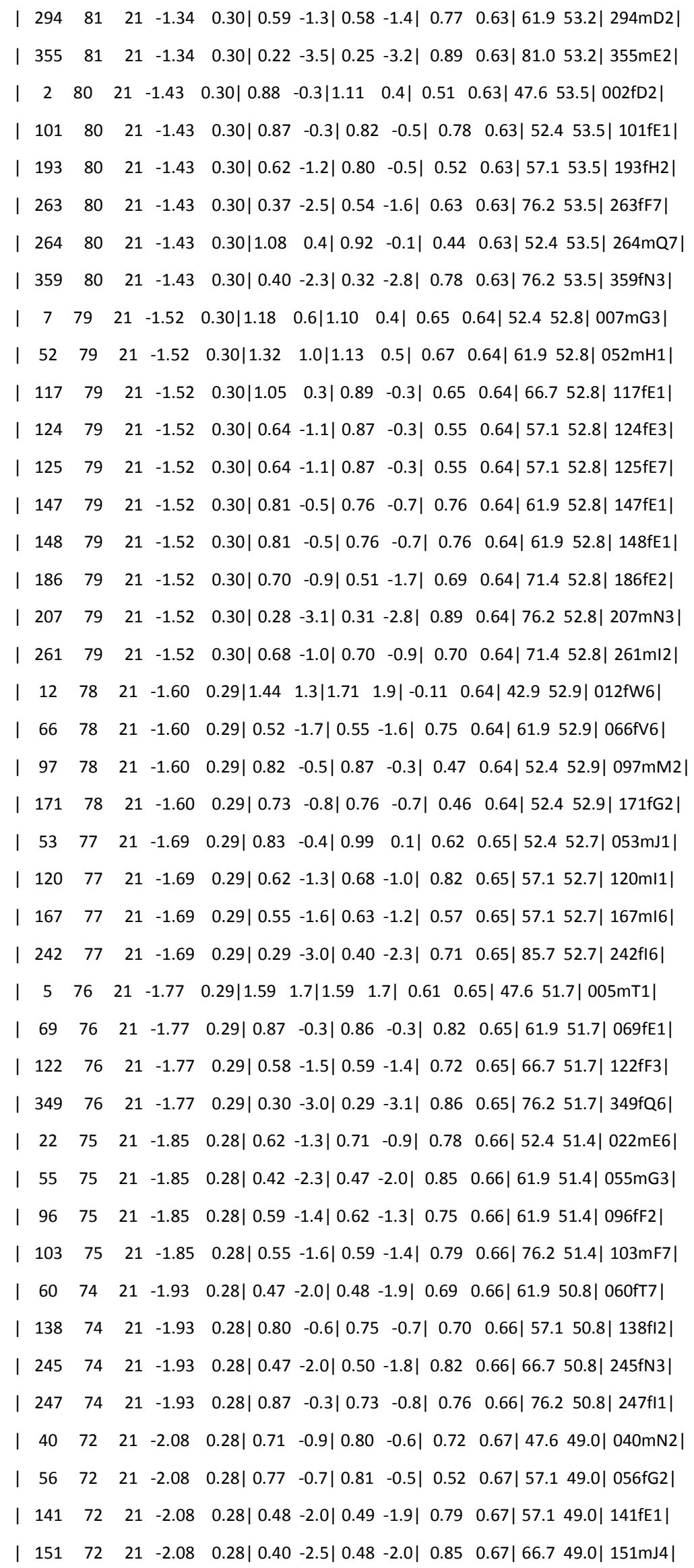




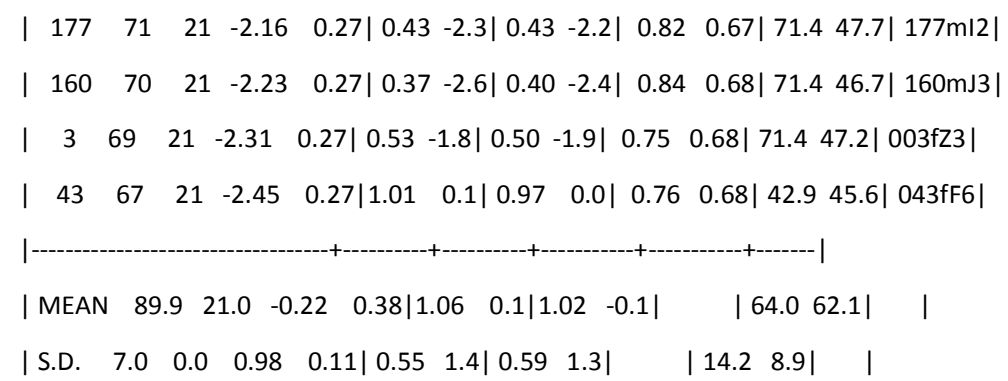

Table 7. Item measure order

|ENTRY TOTAL TOTAL MODELI INFIT | OUTFIT |PT-MEASURE |EXACT MATCH | | |NUMBER SCORE COUNT MEASURE S.E. |MNSQ ZSTD|MNSQ ZSTD|CORR. EXP.| OBS\% EXP\%| Item |

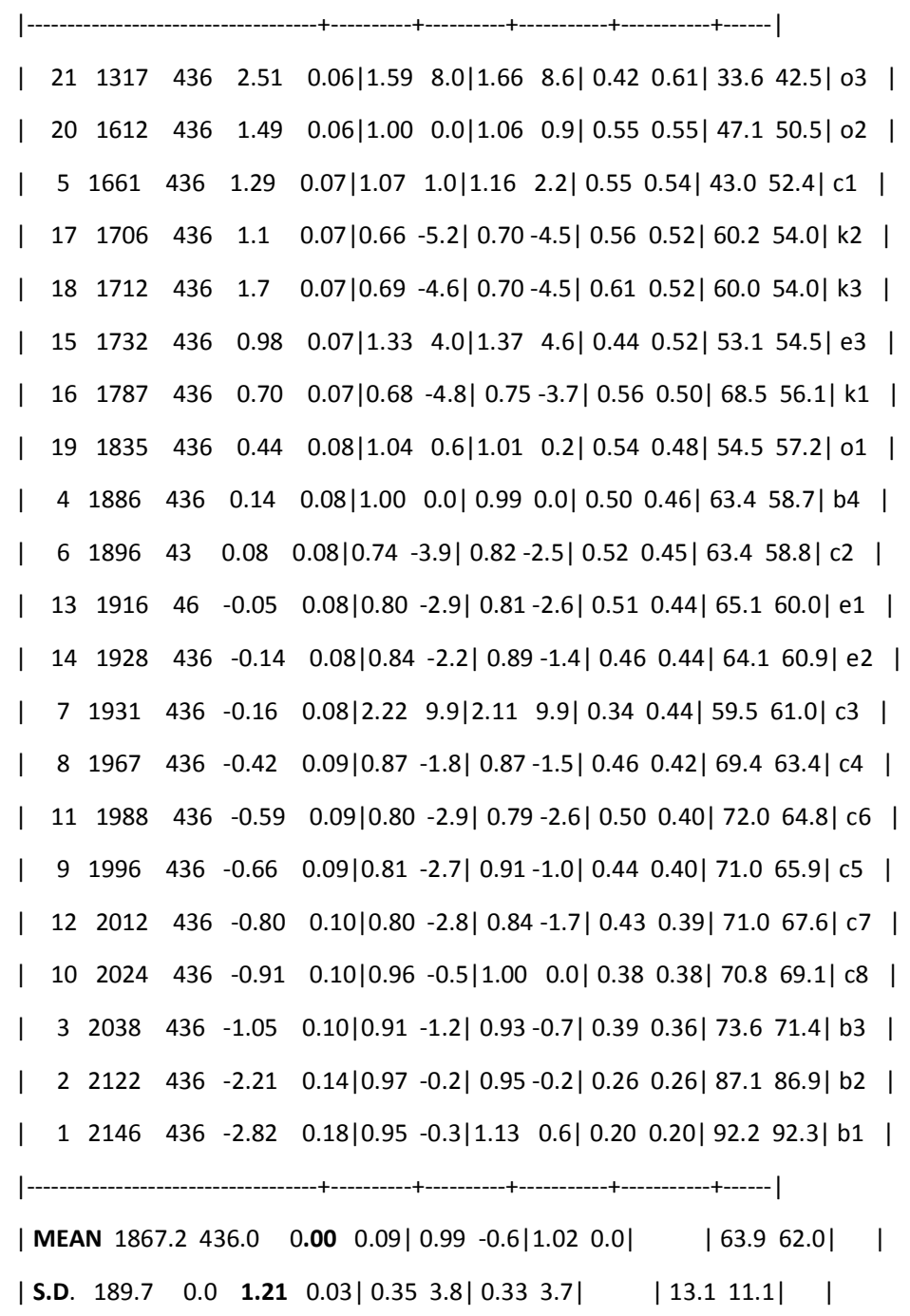


Table 8. Validity and reliabity (Person and item)

SUMMARY OF 435 MEASURED (NON-EXTREME) Person

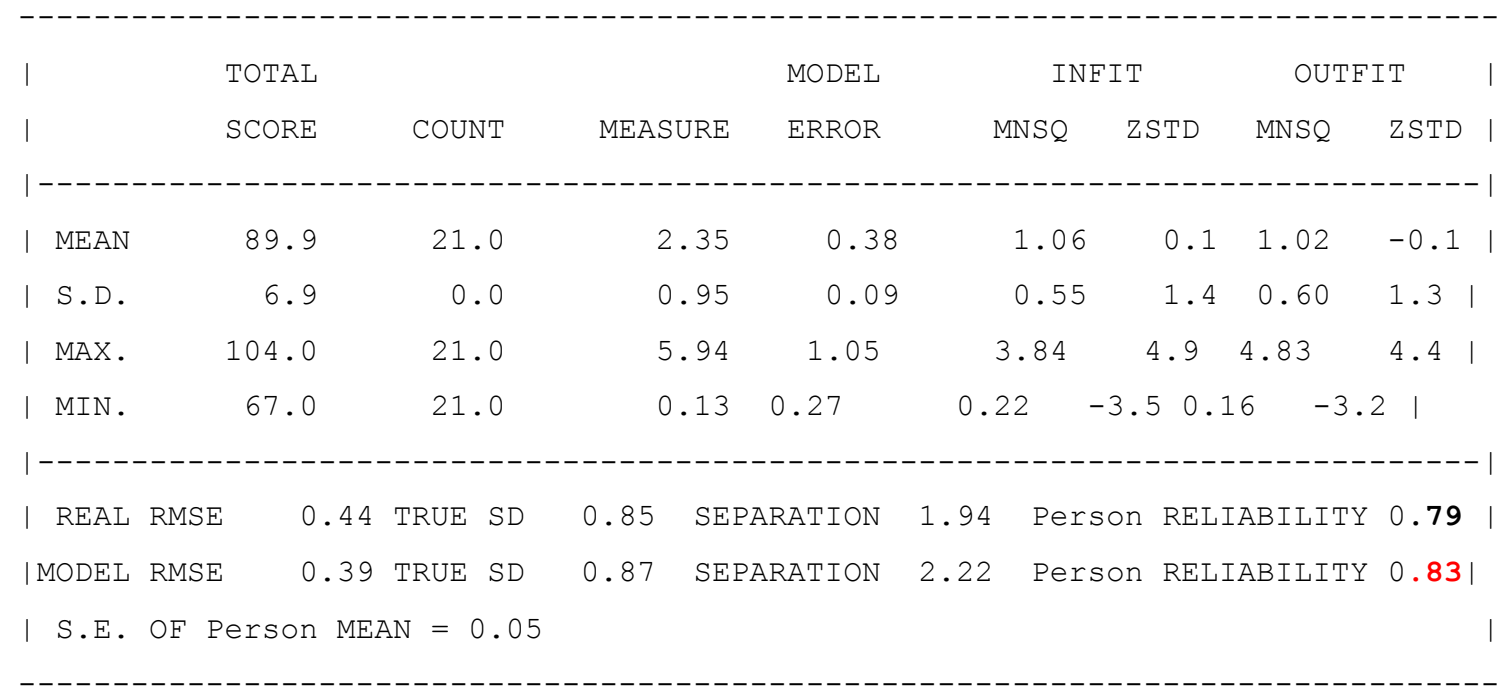

MAXIMUM EXTREME SCORE: 1 Person

SUMMARY OF 436 MEASURED (EXTREME AND NON-EXTREME) Person

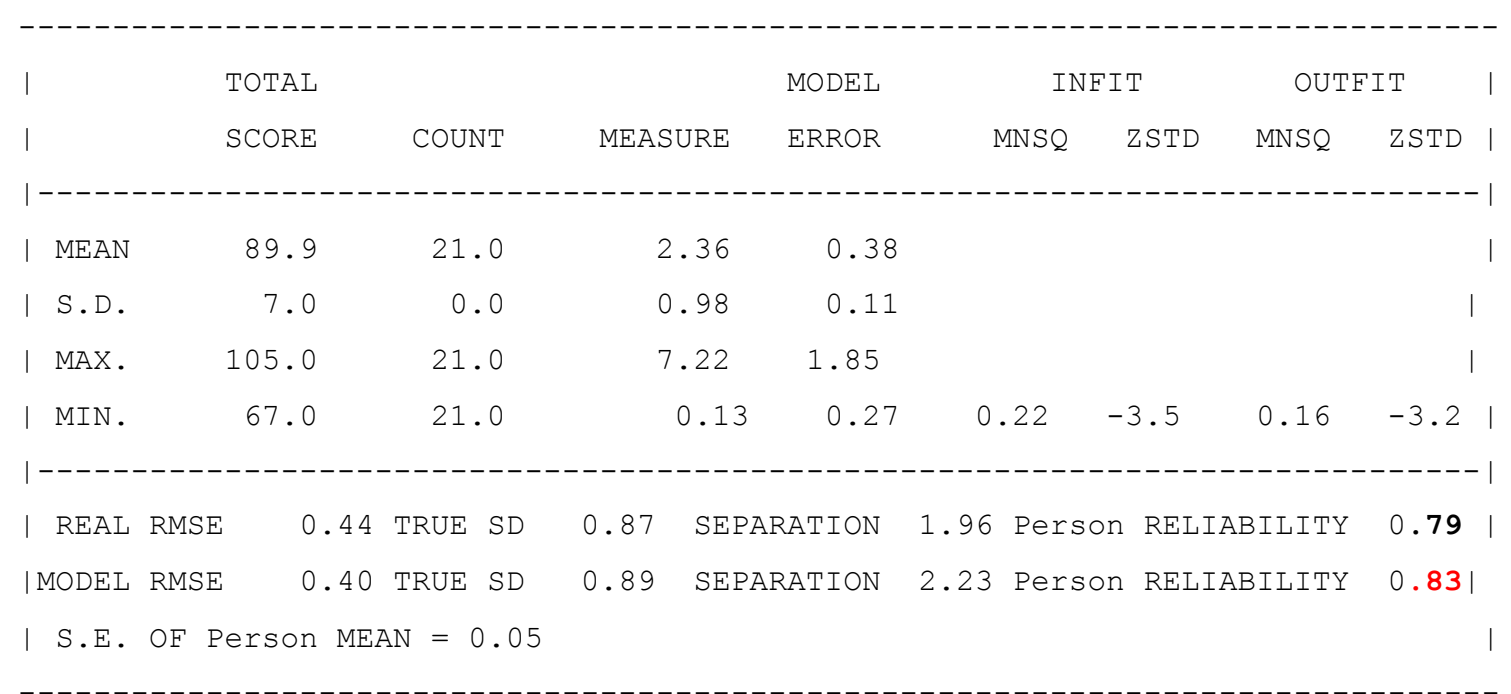

Person RAW SCORE-TO-MEASURE CORRELATION $=0.96$

CRONBACH ALPHA (KR-20) Person RAW SCORE "TEST" RELIABILITY $=.82$ 
SUMMARY OF 21 MEASURED (NON-EXTREME) Item

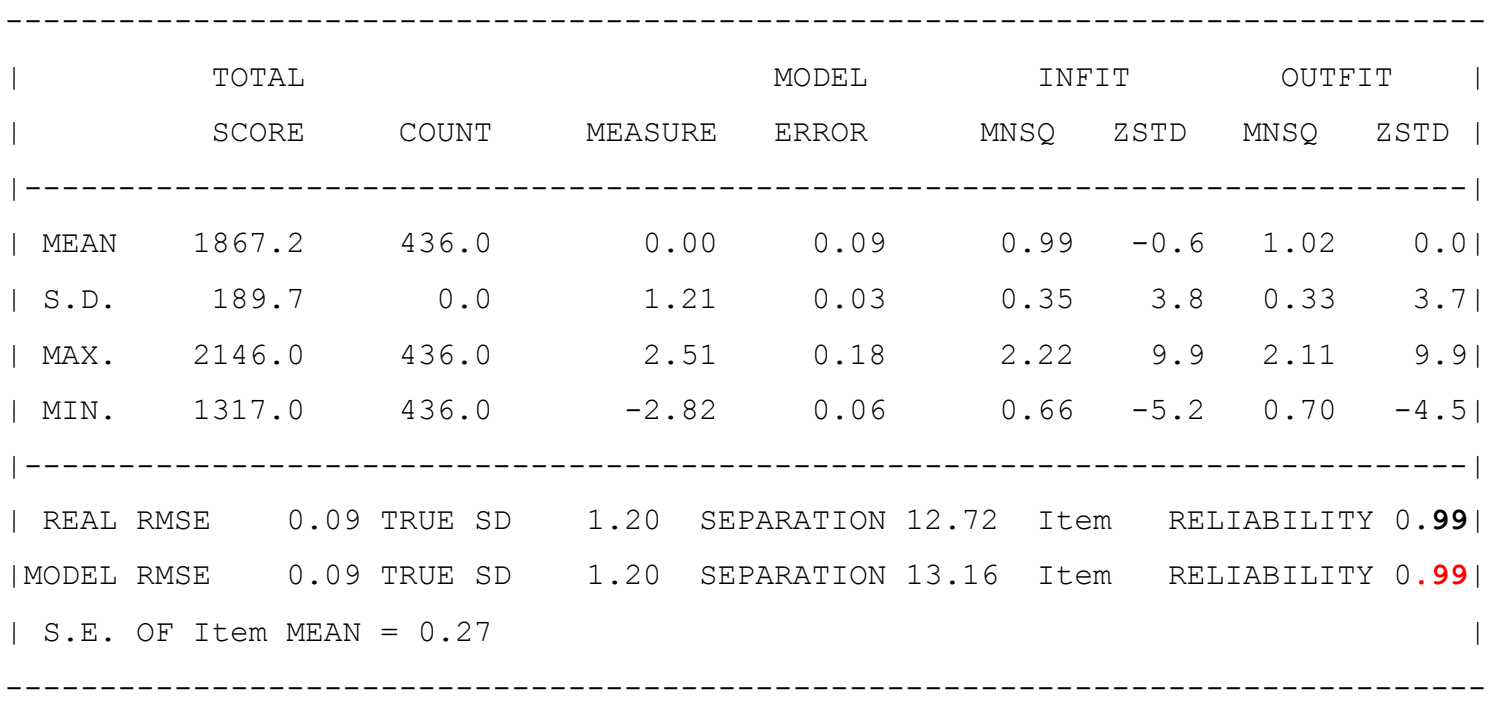

$\mathrm{UMEAN}=.0000 \quad \mathrm{USCALE}=1.0000$

Item RAW SCORE-TO-MEASURE CORRELATION $=-0.95$

9135 DATA POINTS. LOG-LIKELIHOOD CHI-SQUARE: 14926.10 with 8677 d.f. p=0.0000

Global Root-Mean-Square Residual (excluding extreme scores): 0.6106 